\title{
Scrap Tyre Management Pathways and Their Use as a Fuel-A Review
}

\author{
Amir Rowhani ${ }^{1}$ and Thomas J. Rainey ${ }^{1,2, *}$ \\ 1 School of Chemistry, Physics and Mechanical Engineering, Science and Engineering Faculty, \\ Queensland University of Technology, 2 George St, Brisbane, QLD 4000, Australia; \\ amir.rowhani@connect.qut.edu.au \\ 2 Biofuel Engine Research Facility, Queensland University of Technology, 2 George St, \\ Brisbane, QLD 4000, Australia \\ * Correspondence: t.rainey@qut.edu.au; Tel.: +61-7-31381977; Fax: +61-7-31388381 \\ Academic Editor: Thomas E. Amidon \\ Received: 30 August 2016; Accepted: 21 October 2016; Published: 29 October 2016
}

\begin{abstract}
This article provides a review of different methods for managing waste tyres. Around 1.5 billion scrap tyres make their way into the environmental cycle each year, so there is an extreme demand to manage and mitigate the environmental impact which occurs from landfilling and burning. Numerous approaches are targeted to recycle and reuse the tyre rubber in various applications. Among them, one of the most important methods for sustainable environmental stewardship is converting tyre rubber components into bio-oil. In this study, scrap tyre management techniques including landfill, retreading, recycling, combustion, and conversion to liquid fuels was reviewed (including gasification, hydrothermal liquefaction, and pyrolysis). The effects of parameters such as reactor types, pyrolysis temperature, and catalyst on the oil, gas and solid products in pyrolysis process were investigated.
\end{abstract}

Keywords: scrap tyre; bio-oil; pyrolysis; recycling; tyre management

\section{Introduction}

The demand for bioenergy is ever growing due to the depletion of fossil fuels as well as the threats of climate change. One of the greatest challenges in today's modern society is dealing with the disposal or recycling of solid waste produced by human activity [1,2]. The issue of scrap tyres is of great importance due to the major environmental impact that they cause. Over 1.5 billion tonnes of tyres per annum are discarded all around the globe [3-5] weighing 17 million tonnes [6]. In Australia, the number of tyres which are produced annually for passenger cars, trucks and other vehicles is also rapidly increasing. In Australia, the National Tyre Product Stewardship Scheme has been formed to deal with this national problem of end-of-life tyres. According to their report, these tyres are mainly disposed of through landfill or illegally buried in the ground, exported, and only a limited proportion of whole tyres are recycled. The final destination of more than $60 \%$ of end-of-life tyres within Australia is not clear. The majority are comprised of either truck or off-the-road tyres which are used mostly in remote areas. Such a great number of waste tyres is problematic from environmental, social, and financial point of view for both the nation and the world. Around 55 million tyres are expected to reach their end of use by the end of 2014, and it is also projected that this number will be considerably enhanced by 2020. Figure 1 shows the number of end-of-life tyres (equivalent to passenger car tyres) in different areas including metropolitan, regional, and also remote areas of each state of Australia [7]. 


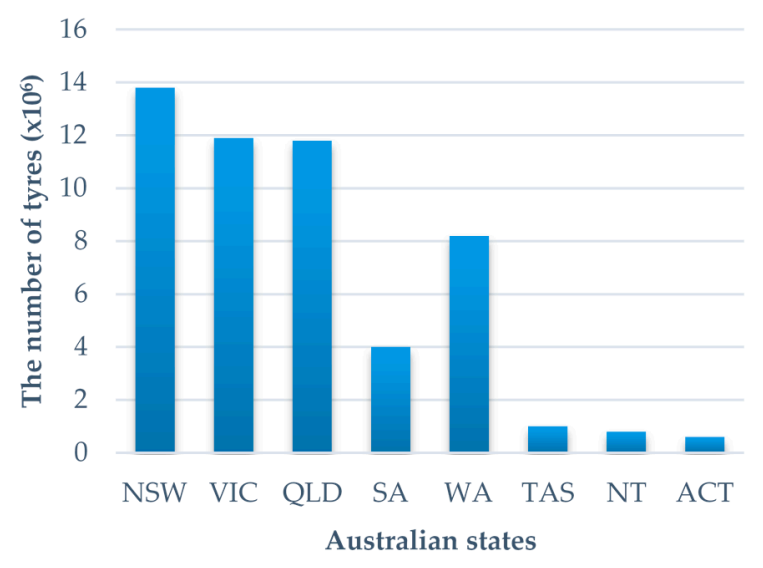

Figure 1. The number of end-of-life tyres in eight states of Australia; New South Wales (NSW), Victoria (VIC), Queensland (QLD), South Australia (SA), Western Australia (WA), Tasmania (TAS), Northern Territory (NT), and Australian Capital Territory (ACT) [7].

To effectively deal with the end-of-life tyre disposal issue, the issue requires substantial funding. Apart from the costs, scarce land space for landfilling, environmental issues and health issues are of chief concern for scrap tyres when they come to the end of their life.

\section{Tyre Composition}

Table 1 represents a breakdown of the various ingredients used in tyre manufacturing $[8,9]$. Regardless of their application all types of tyres are made up of natural rubber in addition to highly complicated synthetic rubbers. Natural rubber (NR) which is the primary material of many tyres is obtained from rubber trees that are harvested in Asia (e.g., Thailand and Indonesia), and Africa. Rubber trees are chiefly cultivated in such areas due to their specific climate and rainy conditions. Natural rubber creates high mechanical resistance and improves thermal stability. Around $40 \%$ of the entire rubber used in tyre manufacturing is natural rubber. NR is used in different parts of the tyre and particularly in the tyre tread. Synthetic rubber which accounts for $\sim 60 \%$ of the rubber used in the tyre structure is a petrochemical by-product which is derived from petroleum hydrocarbons. This rubber is found in the form of styrene-butadiene (SBR) and polybutadiene (PBR). The reason for using synthetic rubber-a highly complex polymeric rubber-is that it can be returned to its initial shape after the stress is relieved. SBR enables tyres to resist deformation at higher temperatures, while NR deforms at comparatively lower temperatures. However, the composition of NR and synthetic rubber is not adequate for tyres to tolerate forces resulting from high-speed automobiles or heavy trucks and aircrafts, so tyre manufacturers apply other materials such as fillers, steel and textiles for reinforcement. Silica and carbon black are the main reinforcement filler materials. By adding $30 \%$ carbon black (CB) to the tyre composition, not only does the resistance increase, but $\mathrm{CB}$ also imparts a distinctive black color. Silica or silicon oxide $\left(\mathrm{SiO}_{2}\right)$ is the main additive to rubber to increase the strength of any ruptures.

Table 1. Comparison of tyre ingredient breakdown for car and truck $[8,9]$.

\begin{tabular}{ccc}
\hline Material & Car Tyre (\%) & Truck Tyre (\%) \\
\hline Natural rubber & 14 & 27 \\
Synthetic rubber & 27 & 14 \\
Fillers (carbon black, silica) & $26-28$ & $26-28$ \\
Plasticizers (oil and resin) & $5-6$ & $5-6$ \\
Chemical additives (sulfur, etc.) & $5-6$ & $5-6$ \\
Metal for reinforcement & 16.5 & 25 \\
Textile for reinforcement & 5.5 & - \\
\hline
\end{tabular}


Some $5 \%$ to $7 \%$ of the tyre's weight is comprised of plasticisers. These plasticisers interact with other components and migrate through the tyre parts. They are critical parts of the tyre components that enhance properties such as durability and rolling resistance on the various ground surfaces. In recent years, due to legislative barriers, tyre manufacturers have mainly used oil or black oil instead of polyaromatic hydrocarbons (PAH).

During the manufacturing process sulfur can be added to the rubber to change the properties of the tyre in a process called vulcanization, whereby at certain temperatures, $\mathrm{C}-\mathrm{H}$ bonds are broken and replaced sulfur atom chains. This vulcanization process forms cross chains in rubber's structure. It was first introduced in 1800-1860 by Charles Goodyear, to convert the sticky natural rubber into a heavily cross-linked polymer. Figure 2 presents the schematic molecule structure of vulcanized rubber. The yellow molecules represent the cross chains that have been formed by sulfur atoms.
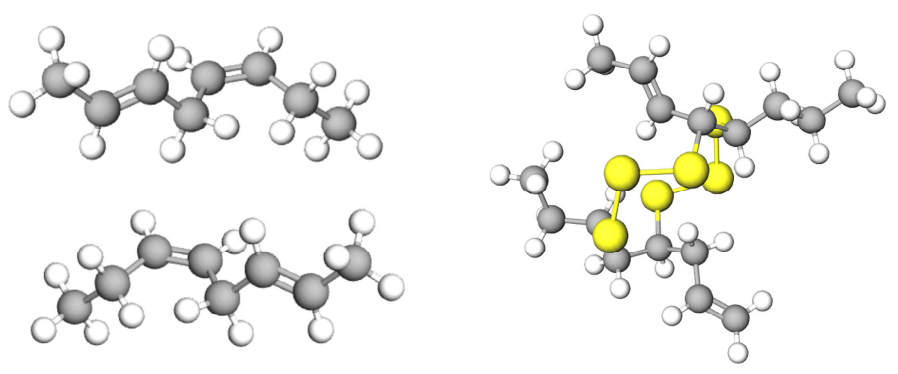

Figure 2. (a) Natural rubber; and (b) vulcanized rubber.

Hence, due to the presence of sulfur in the structure of tyres, the mechanical properties of the final rubber is extremely beneficiated, i.e., the tyre shows better flexibility and resistance to heat. If sulfur is not used in the tyre composition, there is poorer flexing displacement, and this will quickly cause cracks and defects in the tyre. At the final stage, the rubber needs metal and textile for reinforcement to ensure rigidity, flexibility and to aid in maintaining the shape of the tyre. Many manufacturers use steel to provide a strong bond to the tyre rubber and currently it is widely used to reinforce radial tyres. This material provides a high degree of resistance and rigidity to the product. Textiles are another valuable reinforcement material which was first introduced in Concord aircraft tyre technology by the Michelin Company. Fabric reinforcement is extensively applied in high-speed vehicles. Textiles such as nylon and polyester are used for the reinforcement of tyres which can provide considerable ride comfort in the final product $[10,11]$.

\section{Proximate and Ultimate Analysis}

Prior to any tyre treatment, an understanding of the properties of the materials forming the tyre is helpful. Proximate and ultimate analysis of selected tyres are summarized in Tables 2 and 3 [11]. The car and motorcycle tyres contain natural rubber to a lesser extent than that of a truck tyre. Due to the presence of larger organic additives in motorcycle tyres, the energy content is comparatively less than that of truck tyres.

Table 2. Proximate analysis of scrap tyres.

\begin{tabular}{|c|c|c|c|c|c|c|}
\hline Sample Tyre & $\begin{array}{l}\text { Volatile Matter } \\
\text { (wt \%) }\end{array}$ & $\begin{array}{l}\text { Fixed Carbon } \\
\quad(w t \%)\end{array}$ & $\begin{array}{l}\text { Moisture } \\
\text { (wt \%) }\end{array}$ & Ash (wt \%) & $\begin{array}{c}\text { HHV } \\
\left(\mathrm{MJ}^{-\mathrm{kg}^{-1}}\right)\end{array}$ & Reference \\
\hline \multirow{3}{*}{ Car } & 62.2 & 29.4 & 1.3 & 7.1 & 40 & [12] \\
\hline & 58.2 & 21.3 & 1.6 & 18.9 & 35.5 & [13] \\
\hline & 64.97 & 30.08 & 0.75 & 4.6 & 38.6 & [14] \\
\hline \multirow{2}{*}{ Truck } & 66.10 & 27.5 & 1.4 & 5 & 34.4 & [13] \\
\hline & 62.7 & 32.31 & 0.82 & 4.17 & 33.3 & [15] \\
\hline Motorcycle & 57.5 & 20.85 & 1.53 & 20.12 & 29.18 & {$[15,16]$} \\
\hline
\end{tabular}


Table 3. Ultimate analysis of scrap tyres.

\begin{tabular}{|c|c|c|c|c|c|c|}
\hline Sample Tyre & $C(w t \%)$ & $H(w t \%)$ & N (wt \%) & S (wt \%) & $\mathrm{O}(w \mathrm{t} \%)$ & Reference \\
\hline \multirow{3}{*}{ Car } & 86.4 & 8.0 & 0.5 & 1.7 & 3.4 & [12] \\
\hline & 74.3 & 7.2 & 0.9 & 1.71 & 15.89 & [13] \\
\hline & 83.92 & 6.83 & 0.78 & 0.92 & - & [14] \\
\hline \multirow{2}{*}{ Truck } & 83.2 & 7.7 & 1.5 & 1.44 & 6.16 & [13] \\
\hline & 80.3 & 7.18 & 0.5 & 1.19 & 10.8 & [15] \\
\hline Motorcycle & 75.5 & 6.75 & 0.81 & 1.44 & 15.5 & {$[15,16]$} \\
\hline
\end{tabular}

The range of carbon varies from $75.5 \mathrm{wt} \%$ in motorcycle tyres up to $86.4 \mathrm{wt} \%$ in car and truck tyres, however, the contents of hydrogen, nitrogen and sulfur are very similar across different tyres.

\section{Scrap Tyre Management}

Waste or scrap tyres refers to those tyres that have exceeded their expiry date or are not fit for further use. Six million tonnes of scrap tyres are produced annually in USA and Europe [17]. Due to the environmental impacts and relevant health hazards, waste tyre disposal has turned into a major issue and an operational decision needs to be taken to deal with the huge amount of waste tyres produced every year. It is worthwhile mentioning that end-of-life tyres are valuable sources of carbon and can be used as raw materials for many purposes. In the following sections, common approaches to waste tyre recycling are discussed.

\subsection{Landfilling}

One less desirable option for tyre disposal which is becoming even more undesirable in recent years is dumping into open areas and landfilling. Over 4 billion waste tyres are currently stockpiled worldwide [18]. In Australia, approximately $34 \%$ of waste tyres are landfilled. Massive piles of scrap tyres and landfilling are unsustainable management practices and causes countless environmental and health problems. Not only do they occupy a large amount of land (75\% void space), but they also harbour many pests, mosquitos and other insects that spread contagious and unknown diseases [19].

Leaching of metals and other materials is also a threat to the environment as they are eco-toxic and may result in water and soil contamination. Much research has been carried out to investigate the various facets of leaching on the environment and it is indicated that leachate resulted from tyre landfills is toxic to aquatic organisms. Even though the leachate from crumbed tyres or metal pieces are more toxic, whole tyres are more likely to be landfilled. Some factors can be taken into consideration in the amount of pollution created by tyre landfilling. The size of landfilled tyres is critical. When whole tyres are stockpiled, the leachate is likely to be slower than that of shredded tyre. High permeability soil may increase leaching while the time that the water is in contact with the tyres affects leaching [20].

One of the biggest threats of landfilling affecting both the environment and human health is the potential for an uncontrolled fire [21]. Tyres are relatively difficult to ignite, but tyre fires are difficult to extinguish. Many incidents have been reported, and the potential consequences of environmental pollution and health problems have been identified. The gasses emitted from tyre fires are high in $\mathrm{CO}, \mathrm{CO}_{2}$, sulfur oxides, and are harmful to both people and the environment. The firefighting and cleanup from tyre fires are costly. In 1992, almost \$750,000 (AUD) was spent on extinguishing a fire and cleaning up the site at a landfilling area in Queensland, Australia [22]. All these issues mean that there are benefits in moving away from landfilling scrap tyres and to find sustainable management practices.

\subsection{Retreading and Reuse}

Retreading is a process of replacing the tread (outer layer of the tyre) with a new rubber layer by vulcanization [23]. To decide whether or not a tyre can tolerate the retreading process, firstly tyre treads need to be visually inspected. Furthermore, the internal construction of tyres should be checked 
by X-ray. To retread tyres, natural rubber (NR), styrene-butadiene rubber (SBR), polybutadiene rubber (PBR), and chloroprene rubber (CR) for special applications are commonly used [24].

Two methods of retreading are available; cold cure and hot cure. The cold cure method applies to commercial vehicle tyres. This method can be reapplied many times as it does not influence the interior structure. In the cold method, a layer of rubber mixture including NR, SBR, PBR is pressed onto the tyre and vulcanised at $100^{\circ} \mathrm{C}$ for around $4-5 \mathrm{~h}$ depending on the required pattern and size for the treads.

On the other side, hot cure retreading can be applied only once for passenger car tyres [25]. In this method, a fresh layer of rubber is formed on the tyre, and the entire tyre is vulcanised at $150{ }^{\circ} \mathrm{C}$ to $180^{\circ} \mathrm{C}$ to mould the tread pattern [26,27].

Retreading is a very efficient way to save both rubber and energy of end-of-life tyres and could also be considered as part of the solution to the tyre disposal problem [28]. The energy which is used to produce a totally new tyre is 2.3 times greater than that of retreading a used tyre [29]. Due to the high resistance of truck tyres, they can be retreaded three to four times, so from the economical point of view, it could be justified [30]. On the contrary, since retreaded tyres have lower quality, it is usually an undesirable/unacceptable replacement for passenger cars, racing cars and aeroplanes [31].

End-of-life tyres that are not of suitable quality for retreading are used in their original shape for different purposes. Because of their highly elastic property, scrap tyres are a cheap and abundant material suitable for shock and vibration absorbers (e.g., in car or motor racing circuits). Some other applications include protection of the sides of boats from knocks. Scrap tyres can also be used in highway embankments [32], the concrete mixture in building foundations [33,34], and asphalt pavements [35].

\subsection{Energy Recovery}

Waste tyres have a high higher heating value (29-39 MJ. $\mathrm{kg}^{-1}$ ) and are made of around $90 \%$ organic materials so that they can be used as a great source of fuel (known as tyre derived fuel-TDF) through incineration in many applications [36-38]. Tyres can be used without any downsizing (whole tyre) or can be processed into shredded pieces or powder. Since TDF's heating value is higher than that of coal, it is highly suited as a fuel in many combustion applications such as cement kilns, boilers and smelters. In comparison with coal combustion, combustion of TDF is less environmentally hazardous because of the lower emissions [39]. The high temperature of cement kilns enables tyres to be used exclusively rather than coal in this industry [40].

\section{Co-Combustion with Coal}

Coal combustion emissions is one of the big environmental issues in recent years, and there are intensive efforts to find a solution for clean coal combustion. Co-combustion of tyres with coal is a useful way for recovering energy from waste tyres, and also facilitates waste disposal and air pollution reduction. Scrap tyres in the form of shredded or ground tyres can be co-combusted with coal in other industries such as electricity generation by increasing the thermal efficiency of boilers and furnaces and reducing emissions [41-43]. Many researchers proposed the co-firing of pulverised coal and scrap tyre particles for $\mathrm{CO}_{2}$ mitigation. Using waste tyres in conjunction with coal combustion in furnaces may result in resolving a chief environmental issue. Co-combustion of scrap tyre and pulverised coal reduces air pollution, and simultaneously the scrap tyres are utilised effectively.

Singh et al. [43] experimentally studied the co-firing of tyre rubber with pulverised coal in a pilot plant $(80 \mathrm{~kW})$. They showed that pollution reduced by up to $80 \%$ and direct co-firing of coal and tyre reduced the amount of NO produced. In a similar study, Nimmo et al. [44] studied the reburning of waste tyre pulverised fuel to investigate $\mathrm{NO}_{x}$ emissions. It was stated that tyre rubber can be used as a material with fuel potential due to high volatile hydrocarbon content; more than $60 \%$. Moreover, being a great source of hydrocarbon radicals, in addition to the presence of gas hydrocarbons including $\mathrm{CH}_{4}, \mathrm{C}_{2} \mathrm{H}_{6}, \mathrm{C}_{3} \mathrm{H}_{8}, \mathrm{C}_{4} \mathrm{H}_{10}, \mathrm{C}_{4} \mathrm{H}_{8}$, have turned tyre into a potential material capable to reduce 
$\mathrm{NO}_{x}$. Tyres were tested with different particle sizes and $250 \mu \mathrm{m}$ particles were found to be suitable. They reported up to $81 \% \mathrm{NO}_{x}$ reduction by using waste shredded tyre. Giere et al. [38] studied the combustion of a mixture of $95 \%$ coal and 5\% shredded car tyre in a stoker boiler and reported a slight reduction in $\mathrm{CO}$ emissions when tyre was added.

\subsection{Scrap Tyre Recycling}

Since tyres contain a large amount of rubber, a polymeric material, waste tyres can also be used as feed material to create new polymeric products. To be able to blend the scrap tyres to a polymeric raw material, it is required that scrap tyres to be shredded or ground beforehand. In order for tyres to be prepared for fresh polymeric production, various grinding methods would help us to downsize this tough material.

Grinding is a complex process, and as tyres have a high mechanical strength, they need specialized mechanical equipment that is able to shred and grind tyres to a suitably small size and at a great degree of purity. By grinding scrap tyres into very small particles, crumb rubber is produced and may be used as feed for production of other rubber materials and goods. The major obstacle of this method is that the steel and textile utilised in tyre fabrication need to be removed beforehand. It is worthwhile mentioning that the removed steel and textile are recyclable materials as well which can be sold. Also, the textile, after cleaning, can be recovered either by saving its energy (textile combustion) or insulation production $[45,46]$. There are different types of grinding such as mechanical, cryogenic, wet, and high-pressure grinding.

\subsubsection{Mechanical Grinding}

In mechanical grinding, mechanical equipment including a shredder, rolling mills and granulators grind the tyre at ambient temperature. This is repeated until the desired size $-0.3 \mathrm{~mm}-$ is achieved. During the process of grinding, steel and textile are removed with separator and electromagnetic equipment, respectively. The tyre particles should be cooled in order to prevent combustion due to heat released during the mechanical processes [47].

\subsubsection{Cryogenic Grinding}

In the cryogenic method, the tyre is frozen up to $-80--100{ }^{\circ} \mathrm{C}$ using liquid nitrogen and crushed into smaller particles. Steel and textile are removed (like in the mechanical grinding method). One disadvantage of the cryogenic method is the presence of moisture after whole tyres are ground. To reduce the costs associated with this system, a compressor system may replace the liquid nitrogen to decrease the temperature [48]. In a study carried out by Liang and Hao [49], ground particles of rubber were produced. They could grind scrap tyres with a cryogenic grinding system using a separator and vortex mill, and produce particles less than $50 \mu \mathrm{m}$ in size and with very smooth surfaces.

\subsubsection{Wet Grinding}

The wet grinding method can deliver very fine comminuted grain with high surface and volume and with a low level of granulate degradation. In order for tyres to be comminuted through the wet grinding method, they need to be pre-shredded. Then grindstones are used. The continuous water cools the product and grindstones, and the products enter a drying step [50-53].

\subsubsection{Water Jet Grinding}

The water jet grinding method is suitable for large-sized tyres such as those used for tractors, trucks, and so on. A jet of water with high velocity and pressure (above 2000 bar) is used to shred tyres into narrow strips. The advantage is that the ground rubber is of a high degree of purity because during the grinding process the steel material inside tyres remains intact. It is an energy saving and environmentally friendly method. Trained personnel to work with high-pressurized equipment are required $[50,54]$. 


\subsubsection{Berstoff's Method}

This method is a combination of a rolling mill and a screw extruder. With this method of grinding, rough and irregular-shaped particles are produced. The small size grains with the large specific area are advantages of Berstoff's grinding method [50,55]. Table 4 summarizes the advantages and disadvantages of the grinding methods mentioned above.

Table 4. A Comparison of Grinding Methods.

\begin{tabular}{ccc}
\hline Grinding Method & Advantages & Disadvantages \\
\hline Mechanical Grinding & High surface area and volume ratio & $\begin{array}{c}\text { The danger of combustion due to increased temperature, } \\
\text { need for cooling, surface granulation oxidation }\end{array}$ \\
\hline Cryogenic Grinding & $\begin{array}{c}\text { No surface oxidation, } \\
\text { cleaner granulates }\end{array}$ & Expensive liquid nitrogen, high humidity of granulate \\
\hline Wet Grinding & $\begin{array}{c}\text { High surface aera and volume ratio, } \\
\text { decrease of degradation } \\
\text { on granulates }\end{array}$ & Drying after grinding is required \\
\hline Water Jet Grinding & $\begin{array}{c}\text { Environmentally safe, energy saving, } \\
\text { decrease in noise level, no pollutants }\end{array}$ & High pressure equipment, experienced staff \\
\hline Berstoff's Method & $\begin{array}{c}\text { Less humidity, small grain size with } \\
\text { large specific area }\end{array}$ & Not specified \\
\hline
\end{tabular}

Ground waste tyre contains a great amount of both natural and synthetic rubber of a high quality that can be reused by blending with virgin rubber to create a polymeric product. However, the polymer blend has lower mechanical properties in comparison with tyres made of virgin polymer. This comparatively lower mechanical property occurs because inadequate bonds are formed between ground tyre rubber and virgin rubber. Hence, before combining crumbed tyre with new rubber, some modifications to the ground rubber may improve its quality. There are various physical and chemical methods which aim to form polar groups in the surface of the rubber via oxidation. These polar groups created through those physical and chemical processes increase bond formation.

Chemical compounds such as potassium permanganate $\left(\mathrm{KMnO}_{4}\right)$, nitric acid $\left(\mathrm{HNO}_{3}\right)$, sulphuric acid $\left(\mathrm{H}_{2} \mathrm{SO}_{4}\right)$, and hydrogen peroxide $\left(\mathrm{H}_{2} \mathrm{O}_{2}\right)$ can improve the structure of ground waste tyre rubber. Etching the particle surface can increase the adhesion Potassium permanganate was used by Sonnier et al. [56] to break the unsaturated carbon bonds. Nitric and suphuric acids were applied by Colom et al. [37] to improve the ground scrap tyre rubber properties when blended with virgin rubber.

Grafting monomers including styrene, allylamine, acrylamide and methacrylate onto the rubber surface can be carried out through either free-radical initiating or photo initiating to induce polymerization. For this purpose, benzoyl and dicumyl peroxide are commonly used as free initiators, while photochemical grafting is performed through X-ray or UV radiation. Grafting monomers can enhance the compatibility of ground and fresh rubber for structuring and consequently increase the mechanical properties of the rubber blend. These modifications on ground tyre rubber ensure that adequate bond are formed and desirable properties are yielded through better adhesion between crumbed scrap tyre and fresh rubber.

\subsection{Rubber Reclaiming}

The rubber industry, in the beginning, could only rely on natural rubber which was scarce and expensive. Facing the natural rubber shortage forced the industry to find alternative resources to natural rubber in addition to finding a way to reclaim it. Reclaiming rubber from waste rubber products like tyres, tubes and any other rubber products is an appropriate approach to rubber recycling. In terms of scrap tyre management, not only can the rubber reclaiming process resolve the tyre disposal issue, but it could also reduce demands on finite petroleum resources. Reclaimed rubber from waste tyres is extensively used in polymeric blends. Reclaiming is the breaking of carbon bonds while devulcanization is the cleavage of sulfur bonds in the rubber molecular structure. The terms 
devulcanization and reclaiming are often used interchangeably. Although the required energy for breaking the sulfur bonds is comparatively smaller than that of the carbon bonds, it is impractical to specify which bond to be broken.

Through tyre rubber reclaiming, the rubber is softened and swollen due to the breaking of some cross-links as well as double bonds of three-dimensional strong thermoset polymers into two-dimensional thermoplastic products. The reclaimed rubber should have a soluble fraction with a high molecular weight to achieve better mechanical properties of the polymer. Nevertheless, the mechanical properties of reclaimed rubber are lower than that of the virgin rubber. On the other hand, there are some advantages in using reclaimed rubber in producing various rubber articles [57]. Lower energy consumption, lower heat generation, shorter mixing time, faster extrusion, and ultimately reducing the cost of the production are advantages of using reclaimed rubber. This process which is performed by applying an external source of energy is classified into different categories including mechanical, cryogenic, microwave, and ultrasonic treatments [58,59].

\section{Thermochemical Conversion Processes}

Thermochemical conversion processes are a different approach to producing chemicals from various feedstock. Scrap tyres or any biomass can be converted to biofuel through thermochemical processes. These processes include incineration, hydrothermal liquefaction (HTL), gasification and pyrolysis that can also be completed in the presence or absence of catalysts.

\subsection{Gasification}

Gasification is a thermochemical process that converts organic material to a gas mixture (i.e., syngas) as well as minor products such as water, chars at elevated temperature $\left(800-1000^{\circ} \mathrm{C}\right.$ ) and partial pressure. Gasification at high temperature and a controlled environment results in converting a great proportion of the biomass into gas products. Gas products mainly include $\mathrm{CH}_{4}, \mathrm{C}_{2} \mathrm{H}_{6}, \mathrm{H}_{2}$, $\mathrm{CO}, \mathrm{CO}_{2}, \mathrm{O}_{2}$ and char in addition to a small amount of tar. The syngas is predominantly used in gas turbines and engines to produce electricity [60,61]. Gasification reactors come in various styles such as fixed bed, fluidised bed, and entrained bed reactors. A few studies have been conducted on scrap tyre gasification [62-69].

In early work, the effects of temperature on gasification of tyre particles were investigated in a fluidised bed reactor by Raman et al. [62]. They used shredded tyres with particles of $3 \mathrm{~mm}$ diameter and $5 \mathrm{~mm}$ length, at a temperature range of $900-1060 \mathrm{~K}$ with steam. Increasing the temperature led to the gas yield increasing from 0.21 to $0.76 \mathrm{~N} \cdot \mathrm{m}^{3} \cdot \mathrm{kg}^{-1}$, but reducing the gas heating value from 39.6 to $22.2 \mathrm{MJ} \cdot \mathrm{m}^{3}$. The obtained gas was rich in olefins (13.5\% to $34 \%$ ), but depended on the operating temperature. Using steam in fluidised beds yielded higher gas product in comparison to other contactors. Gasification of tyre-char in the temperature range of $850-1000{ }^{\circ} \mathrm{C}$ and $\mathrm{CO}_{2}$ pressure range of $0.3-1.0 \mathrm{~atm}$ showed that the gasification reaction is independent of the char particle size when it is less than $0.65 \mathrm{~mm}[63]$.

Gasification of granulated tyre powder in a wider temperature range from 350 to $900{ }^{\circ} \mathrm{C}$ under air atmosphere was carried out by Leung and Wang [64]. Equivalent ratio (ER), tyre feed rate, and particle size were the most effective parameters for increasing gas yield. At a feeding rate of $11 \mathrm{~m}^{3} \cdot \mathrm{h}^{-1}$, gas with heating value of $6 \mathrm{MJ} \cdot \mathrm{m}^{-3}$ was obtained. Xiao et al. [65] confirmed the results of previous research and stated that increasing both temperature and ER would increase the syngas production, but on the other side, the amount of carbon black decreased. It was reported that at $700{ }^{\circ} \mathrm{C}$, increasing ER from 0.2 to 0.6 increased the syngas yield up to $5.5 \%$, but the amount of carbon black decreased from 600 to $450 \mathrm{~g} \cdot \mathrm{kg}^{-1}$.

Tyre gasification in a rotary kiln reactor yielded syngas with higher hydrogen content as well as methane and ethane [66]. Increasing steam/tyre mass ratio in a rotary kiln reactor had a positive effect on enhancing $\mathrm{CO}$ and hydrogen content in gas products [67]. Various agents such as steam, air $/ \mathrm{CO}_{2}$, and air/steam can be used in tyre gasification processing; steam resulted in a low heating value gas 
of $15.21 \mathrm{MJ} \cdot \mathrm{m}^{-3}$ [68]. In regards to increasing temperature in tyre gasification, gas production is enhanced [69].

Having reviewed the literature, we come to the conclusion that increasing temperature increases yield while other parameters influence the amount and quality of the syngas.

\subsection{Hydrothermal Liquefaction}

HTL is a thermochemical conversion method that enables a wide range of materials to be converted into liquid bio-oil (sometime called bio-crude). HTL operates at higher pressures than other thermochemical techniques with 200-300 bar not uncommon. The key advantage of HTL over pyrolysis is that the feedstock can be processed without any pre-drying [70-72] but yields of liquid fuel are also quite high. However, the fuel properties of the bio-oil resulting from HTL are poor for transportation vehicles compared to that of diesel. To improve the fuel properties, some upgrading techniques such as separation, hydrogenation/hydrotreating, catalytic cracking, and hybrid processes should be applied to improve the fuel properties. Favourable feedstocks for this conversion method is wet or moist lignocellulosic materials such as wood, bagasse, and garbage, in addition to microalgae $[70,73]$. The use of different solvents like acetone, ethanol, water, dichloromethane, diethyl ether and black liquor produce yields in the range $20 \%-40 \%$ [71]. In a recent study, Zhang et al. [6] evaluated the potential of biofuel production of tyres by hydrothermal liquefaction. They carried out experiments in the temperature range of $200-430{ }^{\circ} \mathrm{C}$ in different atmospheres (air, hydrogen, nitrogen, carbon monoxide, and carbon dioxide) and examined the liquid, char, and gas products. They investigate the effects of variables such as temperature, reaction time, water (as solvent) to scrap tyre ratio, and gaseous environment among which temperature was found to be the most influential parameter on the products yield. The obtained $52.73 \mathrm{wt} \%$ oil yield with a heating value of approximately $45 \mathrm{MJ} \cdot \mathrm{kg}^{-1}$ at $400{ }^{\circ} \mathrm{C}$. A key problem with HTL is that the very high pressures requires expensive equipment. To the knowledge of authors, there are only a limited number of research articles dedicated toward scrap tyre conversion into biofuel through gasification and liquefaction; however, great interests have been shown to scrap tyre pyrolysis as considerable oil is yielded.

\subsection{Pyrolysis}

Pyrolysis involves thermal degradation of biomass which occurs at elevated temperature and low pressures. The process normally starts at around $400{ }^{\circ} \mathrm{C}$ and goes further up to even $1000{ }^{\circ} \mathrm{C}$. Significantly, pyrolysis occurs in the absence of oxygen. This pre-condition requires that the feedstock is dried before entering the pyrolysis process. Pyrolysis is formed of two Greek words; "pyro" meaning heat and "lysis" meaning breakdown. Hence, pyrolysis causes larger molecules to breakdown into smaller molecules at elevated temperatures. The chemical reactions include thermal cracking, thermolysis, and depolymerisation. Pyrolysis was applied to produce charcoal more than 5000 years ago [74]. The product yields and composition depend on material particle size, temperature, heating rate, and the condensation temperature of the volatile fraction. Researchers have attempted to advance this technology to make it technically and economically feasible and applied to produce biofuel from various feedstocks. Tyre pyrolysis has been the subject of many studies; a major reason is it is environmentally friendly and its lower emission except for a few equipment leakage and minor fugitive sources [75-81]. Biomass pyrolysis is a very complex process and performed in two stages. Firstly, the volatile matter or vapour is produced and then secondary cracking starts at higher temperatures. The dominant parameters are temperature, reaction time, gaseous atmosphere type and pressure [82].

Pyrolysis of waste tyres is a favourable way of recycling that converts tyres into bio-oil. The tyre rubber is comprised of the highly complex polymeric structure. When the tyre is heated, the cracking process initially starts at $\mathrm{S}-\mathrm{S}$ bonds, since $\mathrm{S}-\mathrm{S}$ bonds need less dissociation energy compared to those of C-C and C-S bonds. The energy required for breaking down the S-S, C-C, and C-S bonds are 429, 607, and $699 \mathrm{~kJ} / \mathrm{mol}$, respectively [83]. Figure 3 shows a tyre molecule with probable positions of thermal crackings that may occur at positions $1-4$. 


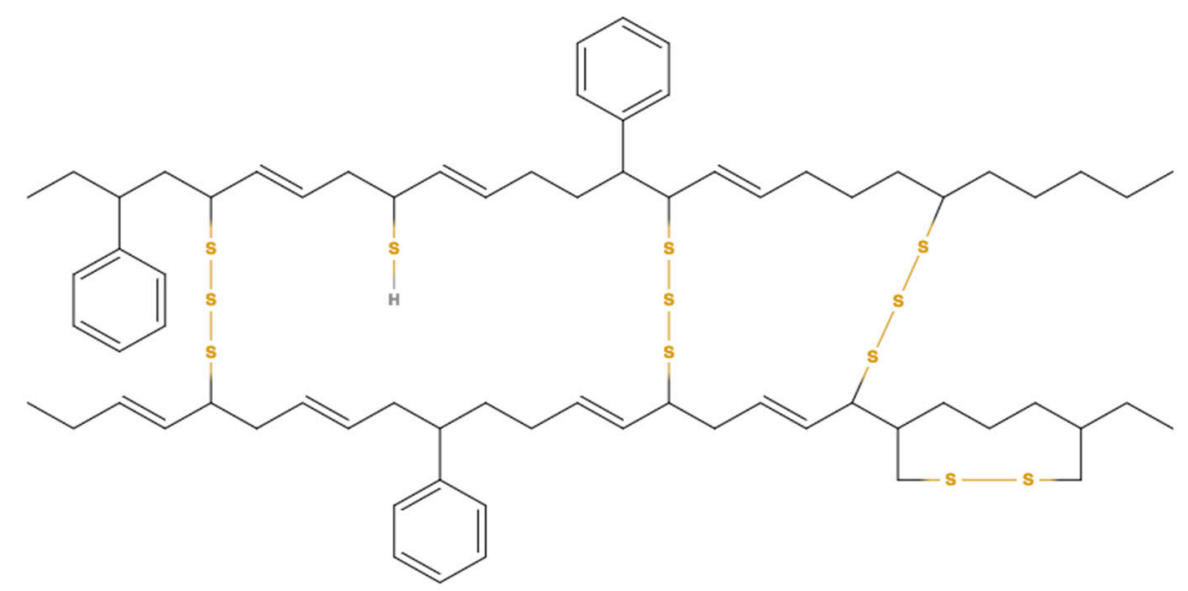

Figure 3. Tyre molecule with possible cracking positions during pyrolysis.

The reactor is an important part of the pyrolysis process. A wide range of reactors including fixed-bed (batch), fluidized-bed, rotary kiln, screw kiln, and vacuum have been used by researchers for scrap tyre pyrolysis among which fixed-bed (batch) reactors is extensively applied in waste tyre pyrolysis. Hita et al. [84] conducted a critical review of tyre pyrolysis based on the reactor types. The heating system is typically an external electric furnace and nitrogen, or another inert gas, is used as a carrier gas. Using a thermogravimetric analysis (TG), it is observed that the tyre thermal degradation temperature commences at around $350{ }^{\circ} \mathrm{C}$. Thus, the pyrolysis temperature range should consider the degradation temperature, and it is normally defined in the range of $450-700{ }^{\circ} \mathrm{C}$. The investigation of rotary kilns fluidised bed and moving bed reactors are more favourable because they are continuous processes even though there are some commercial batch reactors for tyre pyrolysis.

\subsubsection{Fixed-Bed Reactor Pyrolysis}

Research into waste tyre pyrolysis in a fixed-bed reactor commenced in 1983, and only the effect of temperature on product yield was initially investigated [85]. It was observed that increasing the temperature in a larger fixed-bed reactor up to $475{ }^{\circ} \mathrm{C}$ only slightly increased the oil and gas yields. In subsequent research, the temperature increased up to $720^{\circ} \mathrm{C}$ by passing the vapour through a secondary reactor and other effective parameters such as residence time were also examined [86]. Increasing the temperature and residence time resulted in an increase in gas yield from 10 to $20 \mathrm{wt} \%$, but the oil yield decreased from 51.5 to $41.5 \mathrm{wt} \%$.

The effect of heating rate on the tyre pyrolysis products was evaluated by Williams et al. [87]. $50 \mathrm{~g}$ of tyre was used to examine the effect of heating rate $\left(5-80{ }^{\circ} \mathrm{C} \cdot \mathrm{min}^{-1}\right)$ and temperature $\left(300{ }^{\circ} \mathrm{C}\right.$ to $720^{\circ} \mathrm{C}$ ) in a $200 \mathrm{~cm}^{3}$ fixed-bed batch reactor on product yield. At $300{ }^{\circ} \mathrm{C}$, tyre resisted degrading. They observed that by increasing the temperature up to $720^{\circ} \mathrm{C}$, both oil and gas yield increased up to $58.5 \mathrm{wt} \%$ and $14.8 \mathrm{wt} \%$, respectively (at a heating rate of $80^{\circ} \mathrm{C} \cdot \mathrm{min}^{-1}$ ). Only a small change was reported in the products when the heating rate increased from 5 to $80^{\circ} \mathrm{C} \cdot \mathrm{min}^{-1}$. The gas products mostly contained $\mathrm{H}_{2}, \mathrm{CO}, \mathrm{CO}_{2}, \mathrm{C}_{4} \mathrm{H}_{6}, \mathrm{CH}_{4}$, and $\mathrm{C}_{2} \mathrm{H}_{6}$. Fast pyrolysis of the tyre (heating rate of $1200{ }^{\circ} \mathrm{C} \cdot \mathrm{min}^{-1}$ ) showed a direct dependency between pyrolysis temperature and product yields [88]. Increasing the temperature from 500 to $900{ }^{\circ} \mathrm{C}$ can enhance the gas yield from 5.0 to $23 \mathrm{wt} \%$ under fast pyrolysis conditions.

Some studies demonstrated that increasing the temperature resulted in higher oil yield $[84,87,89,90]$. Mastral et al. [89] investigated the effect of various parameters including temperature, heating rate, reaction time, gas velocity, and hydrogen pressure on tyre pyrolysis product yields in a fixed-bed reactor. Increasing the temperature led to higher yields of bio-oil; $45 \mathrm{wt} \%$ oil at $600{ }^{\circ} \mathrm{C}$ while the oil yield was $36 \mathrm{wt} \%$ at $400{ }^{\circ} \mathrm{C}$. Effect of temperature on car tyre pyrolysis in a fixed bed reactor at the temperature range of $300-700{ }^{\circ} \mathrm{C}$ showed both liquid and gas product yields increased [90]. 
The maximum oil of $38.5 \mathrm{wt} \%$ was yielded at $700{ }^{\circ} \mathrm{C}$ which was only $0.5 \mathrm{wt} \%$ higher than the oil obtained at $500{ }^{\circ} \mathrm{C}$.

Another group of researchers reported that the oil yield decreased continuously when the temperature goes up [12,91]. Mastral et al. [91] investigated tyre pyrolysis in a swept fixed-bed reactor and observed a continuous slight decrease in the oil yield from $60.5 \mathrm{wt} \%$ at $450{ }^{\circ} \mathrm{C}$ to $57.5 \mathrm{wt} \%$ at $900{ }^{\circ} \mathrm{C}$. The effect of thermal cracking on conversion products is stronger at higher temperatures and this effect led to lower oil yields. During pyrolysis of small pieces of car tyres $(2-3 \mathrm{~cm})$ in the temperature range $300-700{ }^{\circ} \mathrm{C}$, no changes were observed in oil product above $500{ }^{\circ} \mathrm{C}$ [92]. Removing the fabric and steel of the tyres and performing pyrolysis tests in a fixed bed reactor, Aydin and IIkilic [81] found that the maximum oil yield obtained $40.26 \mathrm{wt} \%$ at $500{ }^{\circ} \mathrm{C}$. At higher temperatures, they observed only a small fall in the oil yield $\left(39.74 \mathrm{wt} \%\right.$ at $\left.700{ }^{\circ} \mathrm{C}\right)$. On the other hand, the maximum gas yield of $18.68 \mathrm{wt} \%$ obtained by temperature rising at $700{ }^{\circ} \mathrm{C}$. They also examined the effect of nitrogen flow rate and did not observe considerable changes in the product yield. In the temperature range of $375-500{ }^{\circ} \mathrm{C}$ and a heating rate of $10{ }^{\circ} \mathrm{C} \cdot \mathrm{min}^{-1}$, an optimum temperature of $425^{\circ} \mathrm{C}$ to obtain maximum oil yield was reported by Kar [93]. The maximum oil yield of $60.02 \mathrm{wt} \%$ obtained at $425{ }^{\circ} \mathrm{C}$ and when temperature increased further up to $500{ }^{\circ} \mathrm{C}$, the oil yield declined to $54.12 \mathrm{wt} \%$. By increasing the temperature during the experiments, the gas product yield continuously increased from $2.99 \mathrm{wt} \%$ at $375{ }^{\circ} \mathrm{C}$ to $20.22 \mathrm{wt} \%$ at $500{ }^{\circ} \mathrm{C}$.

Passenger car and truck tyre pyrolysis was carried out in a fixed bed reactor to investigate the effect of different compositions on product yield [13]. At temperatures of 550, 650 and $850{ }^{\circ} \mathrm{C}$ under the $\mathrm{N}_{2}$ atmosphere, similar gas composition from both car and truck tyres were obtained; $\mathrm{C}_{1}-\mathrm{C}_{4}$ hydrocarbons were observed in both. The physical properties of pyrolytic oils were similar, but the aromatic and sulfur content from car tyres was higher than that of obtained from a truck tyre. The pyrolysis of bicycle, motorcycle, and truck tyres at $375{ }^{\circ} \mathrm{C}$ to $575{ }^{\circ} \mathrm{C}$ in a fixed-bed reactor yielded $45 \mathrm{wt} \%$ to $56.5 \mathrm{wt} \%$ oil products [15]. At higher temperatures of up to $575{ }^{\circ} \mathrm{C}$, the oil yield decreased up to $8 \mathrm{wt} \%$ and the maximum gas product of $20 \mathrm{wt} \%$ yielded.

\subsubsection{Fluidised-Bed Reactor Pyrolysis}

Tyre pyrolysis in fluidised bed reactors has been extensively studied by researchers, and the influence of different parameters have been evaluated [94-98]. In very early research, waste plastic was pyrolysed and it was observed that fluidising sand bed is insensitive to the size of inlet material. Then the design was adapted to test the pyrolysis of whole tyres. Each piece of scrap tyre weighed at least $2.7 \mathrm{~kg}$ [94]. Pyrolysis products comprised of $20-40 \mathrm{wt} \%$ oil and $10-30 \mathrm{wt} \%$ gas. In a pilot plant at $700{ }^{\circ} \mathrm{C}$, the tyre pieces tested each weighed $6-20 \mathrm{~kg}$. It was successful in obtaining $19.6 \mathrm{wt} \%$ oil in addition to $16 \mathrm{wt} \%$ gas products. A feasibility study of fluidized-bed pyrolysis of scrap tyres at lower temperatures was performed by Kaminsky and Mennerrich [96]. They carried out experimental tests in a laboratory-scale $\left(1 \mathrm{~kg} \cdot \mathrm{h}^{-1}\right)$ fluidized-bed reactor which was indirectly heated to between 500 and $600{ }^{\circ} \mathrm{C}$. They investigated the influence of steam as the fluidising gas. Increasing the temperature resulted in increasing the gas, oil and char yields. No significant finding was reported when steam was used as a fluidizing gas at $500{ }^{\circ} \mathrm{C}$. By pyrolysing the truck tyre, the effect of temperature in a fluidized bed reactor was also examined [98]. It was reported that increasing the temperature from 600 to $700{ }^{\circ} \mathrm{C}$ resulted in more oil (30 wt \%) gas (20 wt \%) and carbon black (20 wt \%) yields. Changing the tyre feed rate in fluidized bed reactor demonstrated no change in the products when the feeding rate increased from 0.21 to $0.52 \mathrm{~kg} \cdot \mathrm{h}^{-1}$. However, increasing the temperature from 700 to $880{ }^{\circ} \mathrm{C}$, resulted in an increase in gas yield; however the oil decreased, and the char remained constant [99].

Scrap tyre pyrolysis in a semi-continuous fluidised-bed at a temperature of $450-600^{\circ} \mathrm{C}$ was carried out by Williams and Brindle [100]. The maximum oil yield was $55 \mathrm{wt} \%$ at $450{ }^{\circ} \mathrm{C}$ and increasing the temperature to $600{ }^{\circ} \mathrm{C}$ reduced the oil yield to $43.5 \mathrm{wt} \%$. An increase in gas yield was observed from 2.5 to $14.0 \mathrm{wt} \%$. 
Investigating the effects of temperature $\left(360-810^{\circ} \mathrm{C}\right)$, residence time $(1-5 \mathrm{~s})$, and heating rate in a circulating fluidized-bed reactor on scrap tyre pyrolysis detected that higher temperature and longer residence time would effect on product gas; more methane, ethane, hydrogen, and carbon monoxide and less heavy hydrocarbon gases $\left(\mathrm{C}_{x} \mathrm{H}_{y}\right)$ were obtained. No significant changes were reported on the effect of particle size on the gas composition [101].

\subsubsection{Moving-Bed Reactor Pyrolysis}

Tyre pyrolysis in a rotary kiln reactor has been compared with other types of rectors and the influence of parameters such as temperature, residence time and inert gas flow have been studied. Scrap tyre analysis at a temperature range of $550-680{ }^{\circ} \mathrm{C}$ yielded $38.12 \mathrm{wt} \%$ of oil product at $550{ }^{\circ} \mathrm{C}$ [102]. While the temperature increased, the amount of char produced during the pyrolysis remained almost unchanged. Li et al. [103] studied tyre pyrolysis in a continuous rotary kiln reactor at a temperature range of $450-650{ }^{\circ} \mathrm{C}$. Increasing the temperature, they observed no change in the char fraction. The maximum oil yield of $45.1 \mathrm{wt} \%$ was obtained at $500{ }^{\circ} \mathrm{C}$ with high calorific value $\left(40-42 \mathrm{MJ} \cdot \mathrm{kg}^{-1}\right)$ that enables it to be a used as liquid fuel.

A comparison of tyre pyrolysis in fixed-bed and moving-bed reactors and evaluating the influence of reactor type on yields and product characteristics was conducted by Aylón et al. [104]. Both reactors worked at $600{ }^{\circ} \mathrm{C}$ and used an inert atmosphere. The continuous moving-bed reactor with $15 \mathrm{~kg} \cdot \mathrm{h}^{-1}$ waste tyre throughput demonstrated that all tyre conversion was achieved as well as the fixed-bed reactor in spite of its longer residence time. Due to the longer residence time and faster heating rate in the moving-bed reactor, more primary pyrolysis products and more cracking was observed. Similar char was obtained for both fixed-bed and moving-bed reactors $38 \mathrm{wt} \%$ char yield. On the other hand, moving-bed reactor reduced the oil yield from 54.6 to $43.2 \mathrm{wt} \%$, and increased the product gas yield from 7.5 to $17.1 \mathrm{wt} \%$.

In a further stage, the effects of various parameters were examined for their effect on product yield including temperature, solid residence time and inner gas flow rate in a screw kiln reactor [105]. They observed maximum oil yield of $48.4 \mathrm{wt} \%$ at $600{ }^{\circ} \mathrm{C}$ with a throughput of $8 \mathrm{~kg} \cdot \mathrm{h}^{-1}$. On the other side, they compared their result with a small scaled fixed-bed reactor and observed $56.4 \mathrm{wt} \%$ oil yield that could be caused by the differences in heating rate and gas residence time between the two reactors.

\subsubsection{Vacuum Reactor Pyrolysis}

Another technique which is applicable in tyre pyrolysis is vacuum reactors. Vacuum reactor pyrolysis is based on fluidised bed technology that can pyrolyze larger particles of tyres (up to $50 \mathrm{~mm}$ ) at low pressures. However, due to the operation in a vacuum condition and complicated mechanical structure of the reactor, the maintenance is costly. This reactor works at a lower temperature in comparison to fluidised-bed reactors but yields less oil [106]. Roy and colleagues conducted several vacuum tyre pyrolysis tests to investigate the products yields and quality [107-111]. They pyrolysed recycled scrap tyres at $415^{\circ} \mathrm{C}$ and used a pressure of less than $2 \mathrm{kPa}$ (absolute pressure) and developed a vacuum pyrolysis pilot plant with two different particle sizes [107]. The maximum oil yield was $58.4 \mathrm{wt} \%$, in addition to $6 \%$ of the gas product when tyre particles were $150 \mathrm{~mm}$ to $400 \mathrm{~mm}$. They tested a $200 \mathrm{~kg} \cdot \mathrm{h}^{-1}$ vacuum pyrolysis pilot plant and concluded that it was feasible for a large amount of scrap tyre to be processed.

Pyrolysis of car and truck tyres in a vacuum reactor at $480-520^{\circ} \mathrm{C}$ concluded in obtaining $33 \%$ to $39 \%$ carbon black that can be used as a replacement to commercial carbon blacks for pavement fillers. It was also reported that $43 \%-56 \%$ of the light oil fraction was rich in dl-limonene which is a positive additive to gasoline [108]. Pyrolysis of the crushed tyre in a vacuum reactor showed that when the temperature increased from 450 to $600{ }^{\circ} \mathrm{C}$, the maximum oil yield of $48.8 \mathrm{wt} \%$ and gas yield of $16.3 \mathrm{wt} \%$ was achieved [14]. Increasing the pressure from 25 to $50 \mathrm{kPa}$ as well as the temperature $425-500{ }^{\circ} \mathrm{C}$ resulted in an increase in liquid products and improvement in residual carbon black surface area [112]. 
The quality of light naphtha distilled from pyrolytic oil that was obtained in vacuum tyre pyrolysis showed that $50 \mathrm{wt} \%$ oil yield contained $20 \mathrm{wt} \%$ light naphtha. This light naphtha was found to be rich in aromatic and olifinic compounds with higher octane number and capable of adding to hydrofiner feedstock without influencing the process requirement [109]. Car tyre pyrolysis in a vacuum reactor at $500{ }^{\circ} \mathrm{C}$ obtained $61 \mathrm{wt} \%$ oil that of which contained $18 \mathrm{wt} \%$ naphtha [110].

The effect of pressure on vacuum pyrolysis of scrap tyre was also investigated [113]. It was observed that changing the pressure did not significantly influence the oil, gas, and carbon black yield. By increasing the pressure from 0.8 to $28 \mathrm{kPa}$, the oil yield decreased from 62.2 to $61.7 \mathrm{wt} \%$, and the gas yield increased from 1.0 to $3.2 \mathrm{wt} \%$. However, the oil composition was found to be significantly affected by the pressure. Pakdel et al. [111] pyrolyzed waste tyres of cars and trucks in a continues feed reactor under vacuum condition at a temperature range of $440-570{ }^{\circ} \mathrm{C}$ to produce dl-limonene, a major product which is formed during rubber decomposition. They found that the dl-limonene yield decreased with increasing both temperature and pressure.

\subsubsection{Other Reactors}

Apart from the frequently used pyrolysis reactor designs (i.e., fixed bed, moving bed, and fluidised bed reactors), other innovative designs have been attempted for pyrolysing scrap tyres. One of these designs is the spouted-bed reactor $[112,114,115]$. Olazar et al. [114,115] developed a fluidised-bed reactor which operates with an isothermal process to generate a higher heat transfer rate. A conical spouted bed reduces the residence time of the gas. This reactor had a high production capacity. They obtained a maximum oil yield at $425^{\circ} \mathrm{C}$. Tyre pyrolysis in a spouted bed at a higher temperature resulted in more oil yields. At a temperature range of $425-600{ }^{\circ} \mathrm{C}$, the oil fraction was $55 \mathrm{wt} \%$ at $600{ }^{\circ} \mathrm{C}$ while at $425^{\circ} \mathrm{C}$ only $44 \mathrm{wt} \%$ of oil was obtained [116].

Conesa et al. [117] studied tyre pyrolysis in a drop tube reactor at a pilot plant scale with a system for condensation of semivolatile matter at temperatures of 450,750 , and $1000{ }^{\circ} \mathrm{C}$. In this reactor, after reaching the desirable temperatture, $5 \mathrm{~g}$ tyre was fed into the reactor. Gas was condensed after one hour with dry ice (solid carbon monoxide) placed in the condesation jacket. The char was collected after cooling down the reactor. In this research, it was observed that the amount of solid product increased at higher temperatures. At $1000{ }^{\circ} \mathrm{C}$, the gas products mostly contained methane and benzene. The liquid phase which mainly included styrene, limonene and isoprene decreased from $37.8 \mathrm{wt} \%$ at $450{ }^{\circ} \mathrm{C}$ to $10.9 \mathrm{wt} \%$ at $750{ }^{\circ} \mathrm{C}$.

Pyrolysis of waste car tyres was performed in a captive sample reactor known as a wire mesh microreactor [118]. The influence of the temperature between 390 and $980{ }^{\circ} \mathrm{C}$ was investigated, at a heating rate of $70-90 \mathrm{~K} \cdot \mathrm{s}^{-1}$ under helium atmosphere. The wire mesh microreactor has several advantages; temperature, heating rate and residence time can be independently controlled. Also, the residence time can be very low. The gaseous product is quickly cooled, and the heat transfer is very effective. In these experiments, $200 \mathrm{mg}$ of scrap tyre was cut into small pieces of less than $500 \mathrm{~mm}$ and so the temperature could be rapidly increased to the intended temperature $\left(890^{\circ} \mathrm{C}\right)$. A remarkable increase in gas yield from $22 \mathrm{wt} \%$ at $450{ }^{\circ} \mathrm{C}$ to $73 \mathrm{wt} \%$ at $860{ }^{\circ} \mathrm{C}$ was reported.

Pyrolysis of powdered tyre (200-600 $\mu \mathrm{m})$ in a plasma reactor was performed by Huang and Tang [119]. Using a plasma reactor, they found that using radio frequency (RF) input power of between 1600 and $2000 \mathrm{~W}$ and reactor absolute pressure of between 3000 and 8000 Pa might lead to a temperature of $900-1500{ }^{\circ} \mathrm{C}$. The tyre particles passed through the plasma reactor in nitrogen gas flow. The gas products comprised of hydrogen, methane, carbon monoxide, and carbon dioxide. At $1500{ }^{\circ} \mathrm{C}$, the highest gas amount yielded about $78 \mathrm{wt} \%$.

A two-stage pyrolysis reactor was applied to examine the sulfur content of the pyrolytic oil [120]. A fluidized-bed reactor and an auger reactor were in series. It was observed that less sulfur was formed at $500{ }^{\circ} \mathrm{C}$ compared to $600{ }^{\circ} \mathrm{C}$. In the two-stage reactor, $5.0 \mathrm{wt} \%$ oil with $0.55 \mathrm{wt} \%$ sulfur in auger reactor at $330^{\circ} \mathrm{C}$, and $48 \mathrm{wt} \%$ oil in a fluidized-bed reactor was obtained at $510{ }^{\circ} \mathrm{C}$. A summary of tyre pyrolysis conditions and products is presented in Table 5. 
Table 5. Pyrolysis conditions and products.

\begin{tabular}{|c|c|c|c|c|c|c|c|}
\hline $\begin{array}{l}\text { Reactor } \\
\text { Type }\end{array}$ & $\begin{array}{c}\text { Temperature } \\
\text { Range }\left({ }^{\circ} \mathrm{C}\right)\end{array}$ & $\begin{array}{c}\text { Particle } \\
\text { Size (mm) }\end{array}$ & $\begin{array}{l}\text { Temperature } \\
\text { for Maximum } \\
\text { Oil Yield }\left({ }^{\circ} \mathrm{C}\right)\end{array}$ & $\begin{array}{l}\text { Oil Yield } \\
\text { (wt \%) }\end{array}$ & $\begin{array}{c}\text { Gas Yield } \\
\text { (wt \%) }\end{array}$ & $\begin{array}{c}\text { Char Yield } \\
\text { (wt \%) }\end{array}$ & Reference \\
\hline \multirow{15}{*}{ Fixed-bed } & $300-700$ & $\mathrm{n} / \mathrm{a}^{1}$ & 500 & 40.26 & 11.86 & 47.88 & [81] \\
\hline & $300-720$ & $1.4-2.2$ & 720 & 58.8 & 14.8 & 26.4 & [87] \\
\hline & 950 & $\mathrm{n} / \mathrm{a}^{1}$ & 950 & 20.9 & 23.9 & 40.7 & [121] \\
\hline & $400-600$ & 0.9 & 600 & 45 & $\mathrm{n} / \mathrm{a}^{1}$ & $\mathrm{n} / \mathrm{a}^{1}$ & [82] \\
\hline & $300-700$ & $20-30$ & 700 & 38.5 & 17.8 & 43.7 & [90] \\
\hline & $450-950$ & 0.9 & 450 & 61 & 5 & $\mathrm{n} / \mathrm{a}^{1}$ & [91] \\
\hline & $375-575$ & 1.58 & 475 & 56.5 & 20 & 47.5 & [15] \\
\hline & $375-500$ & 2 & 425 & 60.02 & 20.2 & 26.41 & [93] \\
\hline & $350-600$ & $1-4$ & 400 & 38.8 & 34 & 27.2 & [122] \\
\hline & $300-700$ & $20-30$ & 700 & 38.5 & 17.8 & 43.7 & [92] \\
\hline & $500-720$ & $1.4-2.2$ & 500 & 51.5 & 10 & 37.5 & [86] \\
\hline & $700-880$ & $1.4-2.3$ & 880 & 25 & 40 & 32 & [99] \\
\hline & $500-800$ & $1.5-2$ & 650 & 57.8 & 10 & 36.2 & [13] \\
\hline & $450-600$ & $15-30$ & 475 & 58.2 & $\mathrm{n} / \mathrm{a}^{1}$ & 37.3 & [12] \\
\hline & 600 & 2 & 600 & 54.6 & 7.5 & 38 & [104] \\
\hline \multirow{4}{*}{ Fluidised-bed } & 700 & Whole tyre & 700 & 26.8 & 19 & 35.8 & [94] \\
\hline & $500-600$ & $1-2$ & 600 & 51.0 & 9.1 & 40.0 & [96] \\
\hline & $450-600$ & 1-1.4 & 450 & 55 & 2.5 & 42.5 & [100] \\
\hline & $360-810$ & $0.3-0.88$ & 450 & 52 & $\mathrm{n} / \mathrm{a}^{1}$ & 40 & [101] \\
\hline \multirow{7}{*}{ Moving-bed } & 600 & 2 & 600 & 43.2 & 17.1 & 38 & [104] \\
\hline & $600-800$ & 5 & 600 & 41.5 & 17.9 & 40.6 & [105] \\
\hline & $500-600$ & $10-50$ & 550 & 38 & 29 & 33 & [123] \\
\hline & $550-680$ & $\mathrm{n} / \mathrm{a}^{1}$ & 550 & 38.12 & 2.39 & 49.09 & [123] \\
\hline & $450-650$ & $13-15$ & 500 & 45.1 & 13.6 & 39.8 & [123] \\
\hline & $550-680$ & $\mathrm{n} / \mathrm{a}^{1}$ & 550 & 38.12 & 2.39 & 49.09 & [102] \\
\hline & $450-650$ & $13-15$ & 500 & 45.1 & $\mathrm{n} / \mathrm{a}^{1}$ & 39.8 & [103] \\
\hline \multirow{3}{*}{ Spouted-bed } & $425-500$ & $\mathrm{n} / \mathrm{a}^{1}$ & 425 & 30.5 & 3.3 & 34 & [115] \\
\hline & $425-600$ & 1 & 425 & 54.96 & 1.81 & 33.9 & [33] \\
\hline & $425-500$ & $<1$ & 500 & 57 & 4.5 & 35 & [112] \\
\hline \multirow{10}{*}{ Vacuum } & \multirow{5}{*}{$480-520$} & $6.3-12.7$ & 415 & 56.6 & 2.2 & 36.6 & \multirow{2}{*}{ [107] } \\
\hline & & $150-400$ & 415 & 58.4 & 2.1 & 34.8 & \\
\hline & & $100-120$ & 485 & 43 & 5 & 39 & \multirow{3}{*}{ [108] } \\
\hline & & 20-30 & 550 & 56 & 10 & 33 & \\
\hline & & Whole & 500 & 47 & 5 & 37 & \\
\hline & 510 & $6-12$ & 510 & 50 & 11 & 25 & [109] \\
\hline & $200-500$ & $\mathrm{n} / \mathrm{a}^{1}$ & 500 & 61 & 13 & 26 & [110] \\
\hline & $25-500$ & 1.26 & 500 & 62.2 & 1.0 & 36.8 & [113] \\
\hline & $440-570$ & 1.5 & 500 & 57.5 & 11.9 & 30.6 & [111] \\
\hline & $450-600$ & $0.25-0.85$ & 600 & 48.8 & 16.3 & 34.8 & {$[14]$} \\
\hline
\end{tabular}

\subsection{Catalytic Pyrolysis}

Catalysts accelerate the rate of chemical reactions and remains unconsumed at the end of the process [124]. Pyrolysis reactions can be enhanced in the presence of some catalysts. Pyrolytic oil has some disadvantages including high instability, repolymerisation, ageing and high corrosive property of bio-oil. Using catalysts, on the other hand, changes the product compositions. Catalytic pyrolysis can be carried out in fixed-bed or fluidised bed reactors. In the case of tyre pyrolysis, the catalyst is mixed with scrap tyre pieces in the solid phase. In the next phase of pyrolysis, the vapour contains both catalyst and tyre. Therefore, when the mixed vapour is condensed at the end of the process, the compositions of the products are different. Zeolite is a microporous solid catalyst which is extensively used in catalytic pyrolysis of tyre rubber. Methylsulfonylmethane (MSM), perlites, and zeolites and their family including ZSM-5 and ultrastable Y-type zeolite (USY) are other common catalysts used in tyre pyrolysis $[125,126]$. Several types of research have been conducted to investigate the catalytic pyrolysis of scrap tyres.

The effect of temperature $\left(500-700{ }^{\circ} \mathrm{C}\right)$ and Pt-supported catalyst on polar-aromatic content in waste tyre pyrolysis was investigated by Dũng et al. [127]. They reported that increased pyrolysis temperature led to increasing the content of polar aromatics and the oil yield. Also, they used 
two zeolite-based catalyst-HBETA and HMOR and observed that the polar-aromatic decreased 30\% and $50 \%$ by using HMOR and HBETA, respectively. More reduction in polar-aromatic content is due to the stronger site density, smaller crystallites and the 3D structure of the HBETA. The role of $\mathrm{Pt}$ was to convert polar-aromatics to saturated hydrocarbons, and as a result reducing the amount of polar-aromatics. The effect of adding ITQ-21 and ITQ-24 catalysts as additives into HMOR was investigated in the same apparatus [128]. The results showed that increasing the catalyst-to-tyre ratio, increased the gasoline and kerosene fraction. On the other hand, adding ITQ zeolites, reduced the gasoline production. Both ITQ-21 and ITQ-24 additives increased the oil yield from 40.3 to $41.0 \mathrm{wt} \%$ and $42.4 \mathrm{wt} \%$, respectively. Furthermore, adding ITQ-21 increased the kerosene production whereas the addition of ITQ-24 decreased the kerosene yield. The distinctive influence of the two ITQ zeolites is due to the difference in their acid properties and topology.

Ruthenium $(\mathrm{Ru})$ is a popular catalyst due to its various functionality, high stability in air, and abundance of solvents. Using $\mathrm{Ru}$ as a catalyst in tyre pyrolysis has been considered in some research. Using Ru/SBA-1 in tyre pyrolysis resulted in higher gaseous products yields of up to around two times greater than that of non-catalytic pyrolysis [129]. The highest activity of this catalyst is attributed to the small ruthenium particle size and high sulfur content. In experiments, the content of light fraction increased from 50 to $70 \mathrm{wt} \%$, while the content of poly- and polar aromatic hydrocarbon (PPAH) were reduced. The presence of ruthenium reduced the PPAHs and led to good light oil production. Using MCM-41 and Ru/MCM-41 catalysts on tyre pyrolysis yielded less oil, but more gas products comparing to $\mathrm{Ru} / \mathrm{SBA}-1$ catalyst [130]. The gas yield increased from 11 (non-catalytic) to $15 \mathrm{wt} \%$ and $30 \mathrm{wt} \%$ when using MCM-41 and Ru/MCM-41, respectively. On the other hand, the oil yield was the maximum around $42 \mathrm{wt} \%$ when no catalyst was used. MCM-41 decreased the oil yield to 38 wt \% and $\mathrm{Ru} / \mathrm{MCM}-41$ also decreased to $25 \mathrm{wt} \%$. Using Ru/MCM-41 resulted in light olefins yields of up to four times greater than for non-catalytic pyrolysis. Pyrolysis of $10 \mathrm{~g}$ of tyre at $500{ }^{\circ} \mathrm{C}$ in the presence of MCM-48 and Ru/MCM-48 catalysts revealed more reduction in oil products [131]. Ru/MCM-48 increased the gas yield from $14 \mathrm{wt} \%$ (non-catalytic pyrolysis) to $23 \mathrm{wt} \%$ and $25 \mathrm{wt} \%$ for MCM-48 and $\mathrm{Ru} / \mathrm{MCM}-48$, respectively. Also, the amount of light olefin produced was twice greater than for non-catalytic pyrolysis.

Several researchers have investigated the effect of zeolite and its family on tyre pyrolysis. Shen et al. [132] studied the two-stage pyrolysis of the waste tyre by the use of USY catalyst. They used shredded car tyre $(8.0-10 \mathrm{~mm})$ at $500{ }^{\circ} \mathrm{C}$ in a fixed bed reactor. USY catalyst increased the product gas yield, whereas the oil yield decreased. Also, the oil yield decreased to a large degree when catalyst-tyre ratio increased from 0.25 to 1.0. It was also shown that the high catalyst-tyre ratio increased the light oil fraction (boiling point $<220^{\circ} \mathrm{C}$ ). By increasing the catalyst-tyre ratio to 0.5 , a remarkable change in benzene and toluene concentration was reported. In a similar experiment, they carried out tyre pyrolysis using USY and ZSM-5 catalysts to investigate the effect of catalyst temperature on products yield [133]. USY and ZSM-5 catalysts in tyre pyrolysis reduced the oil yield but increased the yield of gas products. However, the oil yield with the ZSM- 5 catalyst is greater than that of USY catalyst. They reported $54.1 \mathrm{wt} \%$ oil yield for non-catalytic pyrolysis, $40.4 \mathrm{wt} \%$ for ZSM-5 and $32.6 \mathrm{wt} \%$ for USY catalysts. The reason provided for the lower oil yield was the cracking of large molecules to smaller ones.

Three types of different zeolite catalysts including ZSM-5, Y-Zeolite (CBV-400), and Y-Zeolite (CBV-800) in tyre pyrolysis yielded more oil products compared to USY [134]. Using this catalyst increased the yield of gas products by up to $20 \mathrm{wt} \%$. When no catalyst was used, the maximum oil yield was $55.8 \mathrm{wt} \%$ and the minimum gas of $6.1 \mathrm{wt} \%$ was obtained. The use of three catalysts led to an oil reduction among which the ZSM-5 yielded the maximum oil yield of $35.8 \mathrm{wt} \%$ in comparison to Y-zeolite (CBV-400) and Y-zeolite (CBV-780). The different oil yields is due to the difference in catalysts pore size and the ratio of silica/alumina which influenced the number of catalytically active sites on the catalyst surface. 
Investigating the effect of catalyst temperature on oil products shows that by increasing the catalyst temperature from 430 to $600{ }^{\circ} \mathrm{C}$, two different behaviours were observed while two catalysts were used. Using ZSM-5 resulted in an increase in benzene, toluene and xylene. For the Y-zeolite, benzene and toluene increased but caused a reduction in the amount of xylene [135,136].

Investigation of scrap tyre pyrolysis with the presence of Fe-supported zeolites catalysts concluded that introducing $5 \%$ Fe on zeolite catalyst only slightly changed the oil and gas yield. Using $5 \%$, Fe on HZSM- 5 increased the gas products by three wt \% with the expense of $5 \mathrm{wt} \%$ of oil yield [137]. The effect of different catalysts including ZSM-5, USY, Beta, SAPO-11, and ZSM-22 in a batch reactor at $500{ }^{\circ} \mathrm{C}$ was studied by Li et al. [138]. The oil remained almost unchanged (in some cases only a little lower), and reported the maximum oil yield of $55.65 \mathrm{wt} \%$ using ZSM-5. SAPO-11 increased the gas yield up to $10.45 \mathrm{wt} \%$ whereas in the absence of catalyst only $4.5 \mathrm{wt} \%$ gas obtained.

Catalytic pyrolysis of tyre rubber has been known to reduce oil yield, but recent studies showed that some catalysts could increase a number of oil products. Perlite is one of those catalysts that increases the oil yield [93]. Perlite is a volcanic rack capable of expanding up to 35 times bigger than its initial size at a temperature range of $850-1100{ }^{\circ} \mathrm{C}$ [139]. Car tyre pyrolysis with the presence of expanded perlite showed an increase in oil yield up to $65.11 \mathrm{wt} \%$ while pyrolysis without catalyst yielded around $60 \mathrm{wt} \%$ of oil product. There were no significant changes in gas production when using perlite in these experiments [93].

Tyre pyrolysis over calcium carbide $\left(\mathrm{CaC}_{2}\right)$ catalyst showed around $60 \%$ increase in the oil yield comparing to non-catalytic pyrolysis [140]. $\mathrm{CaC}_{2}$ contains pi $(\pi)$ electrons, and vibration of these electrons enhances the vibrational energy of tyres up to resonance and forms polymer radicals. Hence, they are expected to assist greater oil yields. The result showed that in the presence of a catalyst, the oil increases from $22.8 \%$ (non-catalytic) to $38.4 \%$, and the gas product decreased from $37 \%$ (non-catalytic) to $29.6 \%$. Demirbas et al. [141] in a recent study, investigated the tyre pyrolysis with the presence of sodium carbonate $\left(\mathrm{Na}_{2} \mathrm{CO}_{3}\right)$. They used a stainless-steel vertical reactor and carried out their experiments in temperatures range of $400-600{ }^{\circ} \mathrm{C}$. Up to $85 \%$ of the produced oil could be used as fuel in combustion engines. Also, they obtained $49.2 \mathrm{wt} \%$ oil using $10 \%$ catalyst at $485{ }^{\circ} \mathrm{C}$, whereas the oil yield was $39.6 \mathrm{wt} \%$ in the same condition without using a catalyst. Tyre pyrolysis at $430{ }^{\circ} \mathrm{C}$ with the catalyst mixture of ZSM-5 and lubricant base oil (LBO) was carried out by Qu et al. [142]. The mixture of two catalysts significantly increased the degradation rate. It was reported that the oil yield when using ZSM-5 and ZSM-5/LBO was $33.6 \mathrm{wt} \%$ and $48 \mathrm{wt} \%$, respectively. Co-pyrolysis with LBO increased the interaction between tyre and catalysts and consequently enhanced the oil yield and quality.

Using $1.0 \mathrm{~g} \mathrm{MgCl} 2$ as a catalyst in tyre pyrolysis process at $387.5^{\circ} \mathrm{C}$ could increase the oil yield up to $45 \mathrm{wt} \%$ while at the same condition and higher temperature $\left(475^{\circ} \mathrm{C}\right)$ without catalyst the yield was only $19.8 \mathrm{wt} \%$ [143].

Studying the effect of effect of zeolite and calcium carbide $\left(\mathrm{CaC}_{2}\right)$ catalysts as well as the pyrolysis temperature on the product yields of tyre pyrolysis, it was stated that zeolite mostly affected the gasoline production and increased it, while the calcium carbide enhanced the diesel production. However, adding either of the catalysts reduced the amount of fuel oil and heavy oil. They also examined the effect of temperature and reported that by increasing the temperature up to $570{ }^{\circ} \mathrm{C}$, both gasoline and diesel yields increased [144].

Whole tyre pyrolysis was carried out with the presence of a commercial catalyst $\left(\mathrm{CoMo} / \mathrm{Al}_{2} \mathrm{O}_{3}\right.$ $\left.\mathrm{SiO}_{2}\right)$ and $\left(\mathrm{NiMo}-\mathrm{Al}_{2} \mathrm{O}_{3}\right)$ at $360{ }^{\circ} \mathrm{C}$ and $5 \mathrm{MPa}$ of hydrogen pressure and an improvement in fuel characteristic was observed [145]. However, the pyrolytic oil could be used as a component of fuel oils due to the high amount of aromatic hydrocarbons. Table 6 summarizes the tyre pyrolysis with/without presence of catalysts. 
Table 6. Catalytic pyrolysis conditions for tyres and product yields.

\begin{tabular}{|c|c|c|c|c|c|c|c|}
\hline Catalyst & $\begin{array}{c}\text { Catalyst to Tyre } \\
\text { Ratio }\end{array}$ & $\begin{array}{c}\text { Temperature } \\
\left({ }^{\circ} \mathrm{C}\right)\end{array}$ & $\begin{array}{l}\text { Heating Rate } \\
\left({ }^{\circ} \mathrm{C} \cdot \mathrm{min}^{-1}\right)\end{array}$ & $\begin{array}{l}\text { Maximum Liquid } \\
\text { Yield (wt \%) }\end{array}$ & Gas Yield (wt \%) & Solid Yield (wt \%) & Reference \\
\hline Non-catalytic & - & \multirow{5}{*}{500} & \multirow{5}{*}{10} & 44.0 & 10.3 & 45.6 & \multirow{5}{*}{ [128] } \\
\hline HMOR & 0.13 & & & 41.8 & 11.9 & 46.3 & \\
\hline HMOR & 0.33 & & & 35.2 & 17.6 & 47.8 & \\
\hline $\mathrm{HMOR}+2 \%$ ITQ- 24 & - & & & 42.4 & 12.0 & 45.6 & \\
\hline HMOR + $2 \%$ ITQ- 21 & - & & & 41.0 & 13.8 & 45.2 & \\
\hline Non-catalytic & - & \multirow{3}{*}{500} & \multirow{3}{*}{10} & $\sim 42$ & $\sim 10$ & $\sim 43$ & \multirow{3}{*}{ [129] } \\
\hline SBA-1 & - & & & $\sim 41$ & $\sim 13$ & $\sim 44$ & \\
\hline SBA- $1+1 \% \mathrm{Ru}$ & - & & & $\sim 34$ & $\sim 21$ & $\sim 42$ & \\
\hline Non-catalytic & - & \multirow{3}{*}{500} & \multirow{3}{*}{10} & 42 & 11 & 47 & \multirow{3}{*}{ [130] } \\
\hline MCM-41 & 0.25 & & & 38 & 15 & 46 & \\
\hline $\mathrm{MCM}-41+\mathrm{Ru}$ & 0.25 & & & 25 & 30 & 45 & \\
\hline Non-catalytic & - & \multirow{3}{*}{500} & \multirow{3}{*}{10} & 40 & 13 & 47 & \multirow{3}{*}{ [131] } \\
\hline MCM- 48 & 0.25 & & & 33 & 23 & 48 & \\
\hline $\mathrm{MCM}-48+0.7 \% \mathrm{Ru}$ & 0.25 & & & 32 & 26 & 46 & \\
\hline Non-catalytic & - & \multirow{3}{*}{500} & \multirow{3}{*}{10} & 45.9 & 16.5 & 37.59 & \multirow{3}{*}{ [132] } \\
\hline USY & 0.5 & & & $\sim 24$ & $\sim 42$ & $\sim 38$ & \\
\hline USY & 1.0 & & & 13.8 & 19.4 & $\sim 37$ & \\
\hline Non-catalytic & - & \multirow{3}{*}{500} & \multirow{3}{*}{10} & 51.98 & 13.06 & 36.47 & \multirow{3}{*}{ [133] } \\
\hline USY & 0.5 & & & $\sim 21$ & 35.5 & $\sim 38$ & \\
\hline ZSM-5 & 1.0 & & & 32.1 & $\sim 26$ & $\sim 37$ & \\
\hline Non-catalytic & - & \multirow{7}{*}{500} & \multirow{7}{*}{10} & 55.8 & 6.1 & 38.1 & \multirow{7}{*}[134]{} \\
\hline ZSM-5 & 0.5 & & & 47 & 13 & 38 & \\
\hline ZSM-5 & 1.5 & & & 36 & 19 & 38 & \\
\hline Y-Zeolite (CBV-400) & 0.5 & & & 45 & 19 & 38 & \\
\hline Y-Zeolite (CBV-400) & 1.5 & & & 33 & 21 & 38 & \\
\hline Y-Zeolite (CBV-800) & 0.5 & & & 45 & 14 & 38 & \\
\hline Y-Zeolite (CBV-800) & 1.75 & & & 32 & 20 & 38 & \\
\hline Non-catalytic & - & \multirow{3}{*}{500} & \multirow{3}{*}{10} & 55.8 & 6.1 & 38.1 & \multirow{3}{*}{ [135] } \\
\hline Y-Zeolite (CBV-400) & 1.0 & & & $\sim 35$ & $\sim 19$ & $\sim 37$ & \\
\hline ZSM- 5 & 1.0 & & & $\sim 41$ & $\sim 18$ & $\sim 38$ & \\
\hline Non-catalytic & - & \multirow{2}{*}{425} & \multirow{2}{*}{10} & $\sim 60$ & $\sim 10$ & $\sim 30$ & \multirow{2}{*}{ [93] } \\
\hline Perlite & 0.1 & & & 65.11 & $\sim 9$ & $\sim 28$ & \\
\hline
\end{tabular}


Table 6. Cont.

\begin{tabular}{|c|c|c|c|c|c|c|c|}
\hline Catalyst & $\begin{array}{c}\text { Catalyst to Tyre } \\
\text { Ratio }\end{array}$ & $\begin{array}{c}\text { Temperature } \\
\left({ }^{\circ} \mathrm{C}\right)\end{array}$ & $\begin{array}{c}\text { Heating Rate } \\
\left({ }^{\circ} \mathrm{C} \cdot \mathrm{min}^{-1}\right)\end{array}$ & $\begin{array}{l}\text { Maximum Liquid } \\
\text { Yield (wt \%) }\end{array}$ & Gas Yield (wt \%) & Solid Yield (wt \%) & Reference \\
\hline Non-catalytic & - & \multirow{4}{*}{430} & \multirow{4}{*}{10} & 33.3 & 17.7 & 49 & \multirow{4}{*}{ [142] } \\
\hline LBO & 0.05 & & & 33.5 & 14 & 52.2 & \\
\hline ZSM-5 & 0.05 & & & 33.6 & 16 & 50.4 & \\
\hline ZSM-5 + LBO & 0.05 & & & 48 & 9.3 & 42.7 & \\
\hline \multirow{2}{*}{$\begin{array}{c}\text { Non-catalytic } \\
\text { Calcium Carbide } \\
\left(\mathrm{CaC}_{2}\right)\end{array}$} & - & \multirow{2}{*}{400} & \multirow{2}{*}{$\mathrm{n} / \mathrm{a}^{1}$} & 22.8 & 37 & 32 & \multirow{2}{*}{ [140] } \\
\hline & 0.3 & & & 38.4 & 29.6 & $\sim 35$ & \\
\hline \multirow{2}{*}{$\begin{array}{c}\text { Non-catalytic } \\
\text { Sodium Carbonate } \\
\left(\mathrm{Na}_{2} \mathrm{CO}_{3}\right)\end{array}$} & - & \multirow{2}{*}{485} & \multirow{2}{*}{$\mathrm{n} / \mathrm{a}^{1}$} & 39.6 & $\mathrm{n} / \mathrm{a}^{1}$ & $\mathrm{n} / \mathrm{a}^{1}$ & \multirow{2}{*}{ [117] } \\
\hline & 0.1 & & & 49.2 & $\mathrm{n} / \mathrm{a}^{1}$ & $\mathrm{n} / \mathrm{a}^{1}$ & \\
\hline Non-catalytic & - & \multirow{9}{*}{500} & \multirow{9}{*}{10} & $\sim 47.0$ & $\sim 12.0$ & $\sim 43$ & \multirow{9}{*}{ [137] } \\
\hline KL & 0.25 & & & $\sim 44.0$ & $\sim 13.0$ & $\sim 43$ & \\
\hline $\mathrm{KL}+5 \% \mathrm{Fe}$ & - & & & $\sim 43.0$ & $\sim 13.5$ & $\sim 43$ & \\
\hline HBeta & - & & & $\sim 43.0$ & $\sim 9$ & $\sim 43$ & \\
\hline Hbeta $+5 \% \mathrm{Fe}$ & - & & & $\sim 42.0$ & $\sim 11$ & $\sim 43$ & \\
\hline HMOR & - & & & $\sim 44.0$ & $\sim 12$ & $\sim 43$ & \\
\hline $\mathrm{HMOR}+5 \% \mathrm{Fe}$ & - & & & $\sim 42.0$ & $\sim 14$ & $\sim 43$ & \\
\hline HZSM-5 & - & & & $\sim 43.0$ & $\sim 13$ & $\sim 43$ & \\
\hline HZSM- $5+5 \% \mathrm{Fe}$ & - & & & $\sim 38.0$ & $\sim 16$ & $\sim 43$ & \\
\hline Non-catalytic & - & \multirow{6}{*}{500} & \multirow{6}{*}{15} & 55.5 & 4.5 & 40 & \multirow{6}{*}{ [138] } \\
\hline ZSM-5 & 0.01 & & & 55.65 & 6.49 & 37.86 & \\
\hline USY & - & & & 53.49 & 9.97 & 36.54 & \\
\hline Beta & - & & & 54.0 & 8.24 & 34.43 & \\
\hline SAPO-11 & - & & & 55.12 & 10.45 & 38.71 & \\
\hline ZSM-22 & - & & & 55.12 & 6.17 & 40.0 & \\
\hline Non-catalytic & - & 475 & 10 & 19.8 & 24.8 & 55.4 & \multirow{2}{*}{ [143] } \\
\hline $\mathrm{MgCl}_{2}$ & 0.1 & 387.5 & $\mathrm{n} / \mathrm{a}^{1}$ & 45 & 22 & 33 & \\
\hline
\end{tabular}

$1 \mathrm{n} / \mathrm{a}$, not available. 


\subsection{Pyrolytic Oil Properties}

The fuel properties of petroleum-derived fuels including diesel and gasoline are compared to tyre pyrolysis oils. Fuels, like any other material, are specified with some particular properties. These properties can be attributed to fuels from different facets. Physical and chemical properties, primarily, specify the density, thermal capacity, and chemical compositions. Many other properties are attributed to combustion or economics of the fuels. Flash point, for instance, is a term that defines the lowest temperature at which fuel can be ignited in the proximity of air. Other parameters like fuel viscosity, carbon residue, and sulfur content are other important properties that closely related to combustion of the fuels in engines and burners. The higher the fuel density, the more fuel per unit volume can be injected into the engine, and consequently the engine performance and gas emission (carbon monoxide and carbon dioxide) is affected. Viscosity is a restrictive factor in fuel injection and created ignition delay. Low viscosity is desirable for fuel handling and transportation, and leads to greater pump and engine performance. The boiling point range is defined because petroleum products do not have a single boiling point. Initial boiling point and final boiling points also describe the first drop of distillation, and the when the maximum temperature observed. Table 7 summarises the fuel properties of a selected number of pyrolytic oils from the research in this study and compare with those of gasoline and diesel.

Table 7. Tyre-derived oil, gasoline, and diesel properties.

\begin{tabular}{|c|c|c|c|c|c|}
\hline \multirow{2}{*}{ Property } & \multicolumn{3}{|c|}{ Tyre Pyrolysis Oils } & \multirow{2}{*}{$\begin{array}{c}\text { Diesel } \\
{[146,147]}\end{array}$} & \multirow{2}{*}{$\begin{array}{c}\text { Petroleum Gasoline } \\
{[148]}\end{array}$} \\
\hline & [121] & [122] & [16] & & \\
\hline$C(w t \%)$ & 88.00 & 79.96 & 85.86 & 87.4 & 85 \\
\hline $\mathrm{H}(\mathrm{wt} \%)$ & 9.4 & 10.04 & 9.15 & 12.1 & 14.1 \\
\hline $\mathrm{N}(w \mathrm{t} \%)$ & 0.45 & 0.94 & 0.65 & $370^{3}$ & $200^{3}$ \\
\hline$S(w t \%)$ & 1.45 & 0.11 & 1.25 & 0.29 & $280^{3}$ \\
\hline $\mathrm{O}(\mathrm{wt} \%)$ & 0.5 & 9.3 & 2.87 & 0.29 & $\mathrm{n} / \mathrm{a}^{4}$ \\
\hline $\mathrm{H} / \mathrm{C}$ & $\mathrm{n} / \mathrm{a}^{4}$ & 1.51 & 1.27 & $1.76-2.24$ & 1.98 \\
\hline Density $\left(\mathrm{kg} \cdot \mathrm{m}^{-3}\right)$ & $\mathrm{n} / \mathrm{a}^{4}$ & 830 & 957 & 838 & 780 \\
\hline Viscosity (cSt) & $6.30^{2}$ & $1.01^{1}$ & $4.75^{2}$ & $2.1^{2}$ & $\mathrm{n} / \mathrm{a}^{4}$ \\
\hline Flash Point $\left({ }^{\circ} \mathrm{C}\right)$ & 20 & 65 & $\leq 32$ & 54 & 43 \\
\hline $\mathrm{HHV}\left(\mathrm{MJ} \cdot \mathrm{kg}^{-1}\right)$ & 42.1 & 42.66 & $\overline{42.00}$ & 45.5 & 43.9 \\
\hline Moisture content (\%vol) & 4.6 & $\mathrm{n} / \mathrm{a}^{4}$ & $\mathrm{n} / \mathrm{a}^{4}$ & $\mathrm{n} / \mathrm{a}^{4}$ & $\mathrm{n} / \mathrm{a}^{4}$ \\
\hline Boiling points & - & - & $\mathrm{n} / \mathrm{a}^{4}$ & - & - \\
\hline Initial Boiling Point $\left({ }^{\circ} \mathrm{C}\right)$ & 100 & 38.5 & - & 171.5 & 34 \\
\hline $10 \%\left({ }^{\circ} \mathrm{C}\right)$ & 140 & 58.2 & - & 202.4 & 53 \\
\hline $50 \%\left({ }^{\circ} \mathrm{C}\right)$ & 264 & 174.8 & - & 265.6 & 92 \\
\hline $70 \%\left({ }^{\circ} \mathrm{C}\right)$ & $\mathrm{n} / \mathrm{a}^{4}$ & 272.1 & - & $\mathrm{n} / \mathrm{a}^{4}$ & $\mathrm{n} / \mathrm{a}^{4}$ \\
\hline $90 \%\left({ }^{\circ} \mathrm{C}\right)$ & 355 & - & - & 335.8 & 154 \\
\hline Final Boiling Point $\left({ }^{\circ} \mathrm{C}\right)$ & $\mathrm{n} / \mathrm{a}^{4}$ & 382.4 & - & 364.6 & 218 \\
\hline
\end{tabular}

Looking at the properties of pyrolytic oil, one comes to the understanding that with upgrading, the bio-oil properties can be quite similar to diesel and it can be used as an alternative fuel at either full load or blended with diesel. However, there are some problems with these fuels that may affect combustion, engine performance, and emissions. Of eminent concern is the viscosity which is two to three times greater than for diesel. The carbon content is in the same range of diesel fuel, but the nitrogen content is comparatively greater than diesel fuel which leads to worse $\mathrm{NO}_{x}$ emissions. The impurities in the pyrolytic oil can be filtered with filtration methods with $99 \%$ efficiency [147]. Desulfurization and hydrotreating are techniques used by Ramirez et al. [71] to upgrade pyrolytic oil due to the higher amount sulfur and water content. A stability study of tyre pyrolysis fuel over a 12-month period illustrated no changes in viscosity that at room temperature in the absence of light and air. Increasing the temperature showed only a slight reduction in viscosity and so the pyrolytic oil would not be problematic for atomization in diesel engines [16]. 


\section{Conclusions}

Many different techniques have been introduced to deal with the waste tyre disposal issue during the past few decades. Among them, landfilling practice is becoming unsustainable. The approach is typically to either reuse tyres in their original shape or to recycle them. Those tyres that pass required tests and are identified as suitable for retreading go back into reuse. Tyres that are not suitable for retreading are used in creating new products. Tyres are ground using multiple techniques and used as feed for production of other polymeric materials. Combustion of waste tyres to produce biofuel is another common way to recover the energy in the furnaces, boilers, and burners. Thermochemical processes for liquid biofuels including gasification, hydrothermal liquefaction and pyrolysis are commonly used to convert scrap tyres to transportation fuels. Gasification is an applicable method to produce syngas $\left(\mathrm{CH}_{4}, \mathrm{C}_{2} \mathrm{H}_{6}, \mathrm{H}_{2}, \mathrm{CO}, \mathrm{CO}_{2}, \mathrm{O}_{2}\right)$ with up to $39.6 \mathrm{MJ} \cdot \mathrm{m}^{-3}$ heating value. Hydrothermal liquefaction is not very applicable for scrap tyres and is more suitable for woody biomass, bagasse, and algae. The most applicable method of converting tyre to biofuel is pyrolysis. Much research has been carried out to investigate the effects of the various parameters on the oil, gas, and solid yields via pyrolysis. Having reviewed waste tyre pyrolysis, the oil yield is predominantly dependent on temperature, heating rate, and reactor type. Most researchers used fixed beds, moving bed, and fluidized-bed reactors. Only a few other reactor types such as spouted-bed or vacuum reactors were studied. Studying the oil yield, we observed three different trends in oil yield. Some studies reported that increasing the temperature would continuously increase the oil yield $[84,87,89,90]$. In some investigations, it was observed that oil decreased while the temperature increased. In the third category, an optimum temperature was defined at which the oil yield was at a maximum. Unfortunately, we cannot imagine an agreement to predict the oil yield by changing the temperature. However, the gas product yield increases with temperature as the oil cracks at high temperatures. The gas mostly comprises of $\mathrm{H}_{2}, \mathrm{CO}, \mathrm{CO}_{2}, \mathrm{CH}_{4}, \mathrm{C}_{2} \mathrm{H}_{6}, \mathrm{C}_{3} \mathrm{H}_{8}, \mathrm{C}_{2} \mathrm{H}_{4}$. Using the catalysts perlite, $\mathrm{CaC}_{2}$, and $\mathrm{Na}_{2} \mathrm{CO}_{3}$, in tyre pyrolysis increased the oil yield. There is generally no change in the amount of char product while using catalysts. There is also no regular trend in gas product yielded in catalytic pyrolysis. With using perlite, up to $65 \mathrm{wt} \%$ oil was obtained. In the end, the properties of pyrolysis oil, diesel and gasoline have been compared. It is demonstrated that the pyrolytic oil can be used as an alternative to fuels in combustion engines.

Acknowledgments: Publication fees were provided by Queensland University of Technology (QUT).

Author Contributions: This work was developed and written by Amir Rowhani. It was conceived with Thomas J. Rainey who provided major editorial contributions and guidance.

Conflicts of Interest: The authors declare no conflict of interest.

\section{References}

1. Bianchi, M.; Bortolani, G.; Cavazzoni, M.; De Pascale, A.; Montanari, I.; Nobili, M.; Peretto, A.; Tosi, C.; Vecci, R. Preliminary design and numerical analysis of a scrap tires pyrolysis system. Energy Procedia 2014, 45, 111-120. [CrossRef]

2. Martinez, J.D.; Veses, A.; Mastral, A.M.; Murillo, R.; Navarro, M.V.; Puy, N.; Artigues, A.; Bartroli, J.; Garcia, T. Co-pyrolysis of biomass with waste tyres: Upgrading of liquid bio-fuel. Fuel Process. Technol. 2014, 119, 263-271. [CrossRef]

3. Wang, W.C.; Bai, C.J.; Lin, C.T.; Prakash, S. Alternative fuel produced from thermal pyrolysis of waste tires and its use in a di diesel engine. Appl. Therm. Eng. 2016, 93, 330-338. [CrossRef]

4. Su, Y.; Zhao, B. Pyrolysis of Waste Tire Powder and Its Comparison with Shenhua Coal. In Proceedings of the International Conference on Energy and Environment Technology 2009 (ICEET'09), Guilin, China, 16-18 October 2009; pp. 262-265.

5. Parthasarathy, P.; Choi, H.S.; Park, H.C.; Hwang, J.G.; Yoo, H.S.; Lee, B.-K.; Upadhyay, M. Influence of process conditions on product yield of waste tyre pyrolysis-A review. Korean J. Chem. Eng. 2016, 33, 2268-2286. [CrossRef] 
6. Zhang, L.; Zhou, B.; Duan, P.G.; Wang, F.; Xu, Y.P. Hydrothermal conversion of scrap tire to liquid fuel. Chem. Eng. J. 2016, 285, 157-163. [CrossRef]

7. Brindley, E.M.F.; Mountjoy, G. Study into Domestic and International Fate of End-of-Life Tyres; Report No. AA003649-R01-19; Australian Bureau of Statistics: Canberra, Australia, 2012.

8. Erman, B.; Mark, J.E.; Roland, C.M. The Science and Technology of Rubber, 4th ed.; Academic Press: Waltham, MA, USA, 2013.

9. Danon, B.; Gorgens, J. Determining rubber composition of waste tyres using devolatilisation kinetics. Thermochim. Acta 2015, 621, 56-60. [CrossRef]

10. Barlow, C.; Jayasuriya, S.K.; Tan, C.S. The World Rubber Industry; Routledge: Abingdon, NY, USA, 2011.

11. Williams, P.T.; Besler, S. Pyrolysis-thermogravimetric analysis of tires and tyre components. Fuel 1995, 74, 1277-1283. [CrossRef]

12. Cunliffe, A.M.; Williams, P.T. Composition of oils derived from the batch pyrolysis of tyres. J. Anal. Appl. Pyrolysis 1998, 44, 131-152. [CrossRef]

13. Ucar, S.; Karagoz, S.; Ozkan, A.R.; Yanik, J. Evaluation of two different scrap tires as hydrocarbon source by pyrolysis. Fuel 2005, 84, 1884-1892. [CrossRef]

14. Zhang, X.; Wang, T.; Ma, L.; Chang, J. Vacuum pyrolysis of waste tires with basic additives. Waste Manag. 2008, 28, 2301-2310. [CrossRef] [PubMed]

15. Islam, M.R.; Joardder, M.U.H.; Kader, M.A.; Sarker, M.R.I. Valorization of Solid Tire Wastes Available in Bangladesh by Thermal Treatment. In Proceedings of the 2nd International Conference On Solid Waste Management in Developing Countries, Khulna, Bangladesh, 13-15 February 2011.

16. Islam, R.M.; Haniu, H.; Beg, M.R.A. Liquid fuels and chemicals from pyrolysis of motorcycle tire waste: Product yields, compositions and related properties. Fuel 2008, 87, 3112-3122.

17. Williams, P.T. Waste Treatment and Disposal; Wiley: Chichester, UK, 2005.

18. Christensen, T.H. Solid Waste Technology \& Management; Wiley: Chichester, UK, 2011.

19. Torretta, V.; Rada, E.C.; Ragazzi, M.; Trulli, E.; Istrate, I.A.; Cioca, L.I. Treatment and disposal of tyres: Two EU approaches: A review. Waste Manag. 2015, 45, 152-160. [CrossRef] [PubMed]

20. Bazienè, K.; Vaiškūnaitè, R. Research of sustainable use of tire shreds in landfill. Sustainability 2016, 8, 767. [CrossRef]

21. Downard, J.; Singh, A.; Bullard, R.; Jayarathne, T.; Rathnayake, C.M.; Simmons, D.L.; Wels, B.R.; Spak, S.N.; Peters, T.; Beardsley, D.; et al. Uncontrolled combustion of shredded tires in a landfill—Part 1: Characterization of gaseous and particulate emissions. Atmos. Environ. 2015, 104, 195-204. [CrossRef] [PubMed]

22. Matthews, M. Review of Management of Used Tyres at Landfill Sites; Sustainable Strategic Solutions: Perth, Australia, 2006.

23. Flapper, S.D.P.; Nunen, J.A.E.E.; Wassenhove, L.N. Managing Closed-Loop Supply Chains; Springer Science \& Business Media: Berlin, Germany, 2005.

24. Banerjee, B. Tyre Retreading; Smithers Rapra: Bristol, UK, 2015.

25. Dabic-Ostojic, S.; Miljus, M.; Bojovic, N.; Glisovic, N.; Milenkovic, M. Applying a mathematical approach to improve the tire retreading process. Resour. Conserv. Recycl. 2014, 86, 107-117. [CrossRef]

26. Lebreton, B.; Tuma, A. A quantitative approach to assessing the profitability of car and truck tire remanufacturing. Int. J. Prod. Econ. 2006, 104, 639-652. [CrossRef]

27. Zebala, J.; Ciepka, P.; Reza, A.; Janczur, R. Influence of rubber compound and tread pattern of retreaded tyres on vehicle active safety. Forensic Sci. Int. 2007, 167, 173-180. [CrossRef] [PubMed]

28. Amari, T.; Themelis, N.J.; Wernick, I.K. Resource recovery from used rubber tires. Resour. Policy 1999, 25, 179-188. [CrossRef]

29. Ferrão, P.; Ribeiro, P.; Silva, P. A management system for end-of-life tyres: A portuguese case study. Waste Manag. 2008, 28, 604-614. [CrossRef] [PubMed]

30. Beukering, P.J.H.; Janssen, M.A. A dynamic integrated analysis of truck tires in Western Europe. J. Ind. Ecol. 2000, 4, 93-115. [CrossRef]

31. Abdul-Kader, W.; Haque, M.S. Sustainable tyre remanufacturing: An agent-based simulation modelling approach. Int. J. Sustain. Eng. 2011, 4, 330-347. [CrossRef]

32. Bosscher, P.J.; Edil, T.B.; Kuraoka, S. Design of highway embankments using tire chips. J. Geotech. Geoenviron. Eng. 1997, 123, 295-304. [CrossRef] 
33. Sengul, O. Mechanical behavior of concretes containing waste steel fibers recovered from scrap tires. Constr. Build. Mater. 2016, 122, 649-658. [CrossRef]

34. Siddique, R.; Naik, T.R. Properties of concrete containing scrap-tire rubber-An overview. Waste Manag. 2004, 24, 563-569. [CrossRef] [PubMed]

35. Zhou, H.; Holikatti, S.; Vacura, P. Caltrans use of scrap tires in asphalt rubber products: A comprehensive review. J. Traffic Trans. Eng. 2014, 1, 39-48. [CrossRef]

36. Sienkiewicz, M.; Kucinska-Lipka, J.; Janik, H.; Balas, A. Progress in used tyres management in the European Union: A review. Waste Manag. 2012, 32, 1742-1751. [CrossRef] [PubMed]

37. Colom, X.; Canavate, J.; Carrillo, F.; Sunol, J.J. Effect of the particle size and acid pretreatments on compatibility and properties of recycled HDPE plastic bottles filled with ground tyre powder. J. Appl. Polym. Sci. 2009, 112, 1882-1890. [CrossRef]

38. Giere, R.; Smith, K.; Blackford, M. Chemical composition of fuels and emissions from a coal plus tire combustion experiment in a power station. Fuel 2006, 85, 2278-2285. [CrossRef]

39. Conesa, J.A.; Gálvez, A.; Mateos, F.; Martín-Gullón, I.; Font, R. Organic and inorganic pollutants from cement kiln stack feeding alternative fuels. J. Hazard. Mater. 2008, 158, 585-592. [CrossRef] [PubMed]

40. Pipilikaki, P.; Katsioti, M.; Papageorgiou, D.; Fragoulis, D.; Chaniotakis, E. Use of tire derived fuel in clinker burning. Cem. Concr. Compos. 2005, 27, 843-847. [CrossRef]

41. Levendis, Y.A.; Atal, A.; Carlson, J.; Dunayevskiy, Y.; Vouros, P. Comparative study on the combustion and emissions of waste tire crumb and pulverized coal. Environ. Sci. Technol. 1996, 30, 2742-2754. [CrossRef]

42. Courtemanche, B.; Levendis, Y.A. A laboratory study on the $\mathrm{NO}, \mathrm{NO}_{2}, \mathrm{SO}_{2}, \mathrm{CO}$ and $\mathrm{CO}_{2}$ emissions from the combustion of pulverized coal, municipal waste plastics and tires. Fuel 1998, 77, 183-196. [CrossRef]

43. Singh, S.; Nimmo, W.; Gibbs, B.M.; Williams, P.T. Waste tyre rubber as a secondary fuel for power plants. Fuel 2009, 88, 2473-2480. [CrossRef]

44. Nimmo, W.; Singh, S.; Gibbs, B.M.; Williams, P.T. The evaluation of waste tyre pulverised fuel for $\mathrm{NO}_{x}$ reduction by reburning. Fuel 2008, 87, 2893-2900. [CrossRef]

45. Trovatti, E.; Lacerda, T.M.; Carvalho, A.J.F.; Gandini, A. Recycling tires reversible crosslinking of poly(butadiene). Adv. Mater. 2015, 27, 2242-2245. [CrossRef] [PubMed]

46. Holst, O.; Stenberg, B.; Christiansson, M. Biotechnological possibilities for waste tyre-rubber treatment. Biodegradation 1998, 9, 301-310. [CrossRef] [PubMed]

47. Sunthonpagasit, N.; Duffey, M.R. Scrap tires to crumb rubber: Feasibility analysis for processing facilities. Resour. Conserv. Recycl. 2004, 40, 281-299. [CrossRef]

48. Reznik, I. Method and Apparatus for Cooling Air to Cryogenic Temperatures for Recycling Processes. U.S. Patent 6,360,547, 26 March 2002.

49. Liang, S.B.; Hao, Y.C. A novel cryogenic grinding system for recycling scrap tire peels. Adv. Powder Technol. 2000, 11, 187-197. [CrossRef]

50. Ramarad, S.; Khalid, M.; Ratnam, C.T.; Chuah, A.L.; Rashmi, W. Waste tire rubber in polymer blends: A review on the evolution, properties and future. Prog. Mater. Sci. 2015, 72, 100-140. [CrossRef]

51. Brubaker, R.L.; Tloczynski, J.J.; Budzol, M.; Ahola, C.J.; Boyle, F.P.; Parkinson, T.D.; Rine, J.C. Comminuting Apparatus with Improved Rotor and Stator Recess Construction. U.S. Patent 4,469,284, 4 September 1984.

52. Rouse, M.W.; White, M. Rubber Comminuting Apparatus. U.S. Patent 5,654,634, 15 October 1996.

53. Rouse, M.W. Grinding Devices for Rubber Comminuting Machines. U.S. Patent 6,238, 267, 29 May 2001.

54. Rutherford, D. Process for Recycling Vehicle Tires. U.S. Patent 5,115,983, 26 May 1992.

55. Shimada, G. Screw for Extruder and Method of Manufacturing the Extruder, and Rubber Member for Tire and Method of Manufacturing the Rubber Member. U.S. Patent 7,811,075, 12 October 2010.

56. Sonnier, R.; Leroy, E.; Clerc, L.; Bergeret, A.; Lopez-Cuesta, J.M. Polyethylene/ground tyre rubber blends: Influence of particle morphology and oxidation on mechanical properties. Polym. Test. 2007, 26, 274-281. [CrossRef]

57. De, S.K.; Isayev, A.; Khait, K. Rubber Recycling; CRC Press: Boca Raton, FL, USA, 2005.

58. Bandyopadhyay, S.; Agrawal, S.L.; Ameta, R.; Dasgupta, S.; Mukhopadhyay, R.; Deuri, A.S.; Ameta, S.C.; Ameta, R. An overview of rubber recycling. Prog. Rubber Plast. Recycl. Technol. 2008, 24, 73-112.

59. Rajan, V.V.; Dierkes, W.K.; Joseph, R.; Noordermeer, J.W.M. Science and technology of rubber reclamation with special attention to NR-based waste latex products. Prog. Polym. Sci. 2006, 31, 811-834. [CrossRef] 
60. Nikrityuk, P.A.; Meyer, B. Gasification Processes: Modeling and Simulation; Wiley-VCH: Weinheim, Germany, 2014.

61. Higman, C.; van der Burgt, M. Gasification; Gulf Publishing Company: Houston, TX, USA, 2003.

62. Raman, K.P.; Walawender, W.P.; Fan, L.T. Gasification of waste tires in a fluid bed reactor. Conserv. Recycl. 1981, 4, 79-88. [CrossRef]

63. Lee, J.S.; Sang, D.K. Gasification kinetics of waste tire-char with $\mathrm{CO}_{2}$ in a thermobalance reactor. Energy 1996, 21, 343-352. [CrossRef]

64. Leung, D.Y.C.; Wang, C.L. Fluidized-bed gasification of waste tire powders. Fuel Process. Technol. 2003, 84, 175-196. [CrossRef]

65. Xiao, G.; Ni, M.-J.; Chi, Y.; Cen, K.-F. Low-temperature gasification of waste tire in a fluidized bed. Energy Convers. Manag. 2008, 49, 2078-2082. [CrossRef]

66. Galvagno, S.; Casciaro, G.; Casu, S.; Martino, M.; Mingazzini, C.; Russo, A.; Portofino, S. Steam gasification of tyre waste, poplar, and refuse-derived fuel: A comparative analysis. Waste Manag. 2009, 29, 678-689. [CrossRef] [PubMed]

67. Donatelli, A.; Iovane, P.; Molino, A. High energy syngas production by waste tyres steam gasification in a rotary kiln pilot plant. Experimental and numerical investigations. Fuel 2010, 89, 2721-2728. [CrossRef]

68. Karatas, H.; Olgun, H.; Akgun, F. Experimental results of gasification of waste tire with air\& $\mathrm{CO}_{2}$, air\&steam and steam in a bubbling fluidized bed gasifier. Fuel Process. Technol. 2012, 102, 166-174.

69. Portofino, S.; Donatelli, A.; Iovane, P.; Innella, C.; Civita, R.; Martino, M.; Matera, D.A.; Russo, A.; Cornacchia, G.; Galvagno, S. Steam gasification of waste tyre: Influence of process temperature on yield and product composition. Waste Manag. 2013, 33, 672-678. [CrossRef] [PubMed]

70. Kosinkova, J.; Doshi, A.; Maire, J.; Ristovski, Z.; Brown, R.; Rainey, T.J. Measuring the regional availability of biomass for biofuels and the potential for microalgae. Renew. Sustain. Energy Rev. 2015, 49, 1271-1285. [CrossRef]

71. Ramirez, J.A.; Brown, R.J.; Rainey, T.J. A review of hydrothermal liquefaction bio-crude properties and prospects for upgrading to transportation fuels. Energies 2015, 8, 6765-6794. [CrossRef]

72. Kosinkova, J.; Ramirez, J.A.; Nguyen, J.; Ristovski, Z.; Brown, R.; Lin, C.S.K.; Rainey, T.J. Hydrothermal liquefaction of bagasse using ethanol and black liquor as solvents. Biofuels Bioprod. Biorefining 2015, 9, 630-638. [CrossRef]

73. Doshi, A.; Pascoe, S.; Coglan, L.; Rainey, T.J. Economic and policy issues in the production of algae-based biofuels: A review. Renew. Sustain. Energy Rev. 2016, 64, 329-337. [CrossRef]

74. Antal, M.J., Jr.; Grønli, M. The art, science, and technology of charcoal production. Ind. Eng. Chem. Res. 2003, 42, 1619-1640. [CrossRef]

75. Clark, C.; Meardon, K.; Russell, D. Scrap Tire Technology and Markets; Noyes Data Corp.: Park Ridge, NJ, USA, 1993.

76. Demirbas, A. The influence of temperature on the yields of compounds existing in bio-oils obtained from biomass samples via pyrolysis. Fuel Process. Technol. 2007, 88, 591-597. [CrossRef]

77. Williams, P.T.; Bottrill, R.P. Sulfur-polycyclic aromatic-hydrocarbons in tyre pyrolysis oil. Fuel 1995, 74, 736-742. [CrossRef]

78. Unapumnuk, K.; Keener, T.C.; Lu, M.; Liang, F. Investigation into the removal of sulfur from tire derived fuel by pyrolysis. Fuel 2008, 87, 951-956. [CrossRef]

79. Murugan, S.; Ramaswamy, M.C.; Nagarajan, G. A comparative study on the performance, emission and combustion studies of a di diesel engine using distilled tyre pyrolysis oil-diesel blends. Fuel 2008, 87, 2111-2121. [CrossRef]

80. İlkılıç, C.; Aydın, H. Fuel production from waste vehicle tires by catalytic pyrolysis and its application in a diesel engine. Fuel Process. Technol. 2011, 92, 1129-1135. [CrossRef]

81. Aydın, H.; Ilkiliç, C. Optimization of fuel production from waste vehicle tires by pyrolysis and resembling to diesel fuel by various desulfurization methods. Fuel 2012, 102, 605-612. [CrossRef]

82. Quek, A.; Balasubramanian, R. Low-energy and chemical-free activation of pyrolytic tire char and its adsorption characteristics. J. Air Waste Manag. Assoc. 2009, 59, 747-756. [PubMed]

83. Dean, J.A. Lange's handbook of chemistry. Mater. Manuf. Process. 1990, 5, 687-688. [CrossRef] 
84. Hita, I.; Arabiourrutia, M.; Olazar, M.; Bilbao, J.; Arandes, J.M.; Castano, P. Opportunities and barriers for producing high quality fuels from the pyrolysis of scrap tires. Renew. Sustain. Energy Rev. 2016, 56, 745-759. [CrossRef]

85. Dodds, J.; Domenico, W.F.; Evans, D.R.; Fish, L.W.; Lassahn, P.L.; Toth, W.J. Scrap Tyres: A Resource and Technology Evaluation of Tyre Pyrolysis and Other Selected Alternative Technologies; US Department of Energy Report: Washington, DC, USA, 1983.

86. Williams, P.T.; Taylor, D.T. Aromatization of tyre pyrolysis oil to yield polycyclic aromatic hydrocarbons. Fuel 1993, 72, 1469-1474. [CrossRef]

87. Williams, P.T.; Besler, S.; Taylor, D.T. The pyrolysis of scrap automotive tyres: The influence of temperature and heating rate on product composition. Fuel 1990, 69, 1474-1482. [CrossRef]

88. Leung, D.Y.C.; Yin, X.L.; Zhao, Z.L.; Xu, B.Y.; Chen, Y. Pyrolysis of tire powder: Influence of operation variables on the composition and yields of gaseous product. Fuel Process. Technol. 2002, 79, 141-155. [CrossRef]

89. Mastral, A.M.; Murillo, R.; Callén, M.S.; García, T.; Snape, C.E. Influence of process variables on oils from tire pyrolysis and hydropyrolysis in a swept fixed bed reactor. Energy Fuel. 2000, 14, 739-744. [CrossRef]

90. De Marco Rodriguez, I.; Laresgoiti, M.F.; Cabrero, M.A.; Torres, A.; Chomón, M.J.; Caballero, B. Pyrolysis of scrap tyres. Fuel Process. Technol. 2001, 72, 9-22. [CrossRef]

91. Mastral, A.M.; Murillo, R.; García, T.; Navarro, M.V.; Callen, M.S.; López, J.M. Study of the viability of the process for hydrogen recovery from old tyre oils. Fuel Process. Technol. 2002, 75, 185-199. [CrossRef]

92. Laresgoiti, M.F.; Caballero, B.M.; de Marco, I.; Torres, A.; Cabrero, M.A.; Chomón, M.J. Characterization of the liquid products obtained in tyre pyrolysis. J. Anal. Appl. Pyrolysis 2004, 71, 917-934. [CrossRef]

93. Kar, Y. Catalytic pyrolysis of car tire waste using expanded perlite. Waste Manag. 2011, 31, 1772-1782. [CrossRef] [PubMed]

94. Kaminsky, W. Pyrolysis of plastic waste and scrap tyres in a fluid bed reactor. Resour. Recovery Conserv. 1980, 5, 205-216. [CrossRef]

95. Kaminsky, W. Thermal recycling of polymers. J. Anal. Appl. Pyrolysis 1985, 8, 439-448. [CrossRef]

96. Kaminsky, W.; Mennerich, C. Pyrolysis of synthetic tire rubber in a fluidised-bed reactor to yield 1,3-butadiene, styrene and carbon black. J. Anal. Appl. Pyrolysis 2001, 58, 803-811. [CrossRef]

97. Kaminsky, W.; Predel, M.; Sadiki, A. Feedstock recycling of polymers by pyrolysis in a fluidised bed. Polym. Degrad. Stab. 2004, 85, 1045-1050. [CrossRef]

98. Kaminsky, W.; Mennerich, C.; Zhang, Z. Feedstock recycling of synthetic and natural rubber by pyrolysis in a fluidized bed. J. Anal. Appl. Pyrolysis 2009, 85, 334-337. [CrossRef]

99. Lee, J.M.; Lee, J.S.; Kim, J.R.; Kim, S.D. Pyrolysis of waste tires with partial oxidation in a fluidized-bed reactor. Energy 1995, 20, 969-976. [CrossRef]

100. Williams, P.T.; Brindle, A.J. Fluidised bed pyrolysis and catalytic pyrolysis of scrap tyres. Environ. Technol. 2003, 24, 921-929. [CrossRef] [PubMed]

101. Dai, X.; Yin, X.; Wu, C.; Zhang, W.; Chen, Y. Pyrolysis of waste tires in a circulating fluidized-bed reactor. Energy 2001, 26, 385-399. [CrossRef]

102. Galvagno, S.; Casu, S.; Casabianca, T.; Calabrese, A.; Cornacchia, G. Pyrolysis process for the treatment of scrap tyres: Preliminary experimental results. Waste Manag. 2002, 22, 917-923. [CrossRef]

103. Li, S.Q.; Yao, Q.; Chi, Y.; Yan, J.H.; Cen, K.F. Pilot-scale pyrolysis of scrap tires in a continuous rotary kiln reactor. Ind. Eng. Chem. Res. 2004, 43, 5133-5145. [CrossRef]

104. Aylón, E.; Fernández-Colino, A.; Navarro, M.V.; Murillor, R.; García, T.; Mastral, A.M. Waste tire pyrolysis: Comparison between fixed bed reactor and moving bed reactor. Ind. Eng. Chem. Res. 2008, 47, 4029-4033. [CrossRef]

105. Aylón, E.; Fernández-Colino, A.; Murillo, R.; Navarro, M.V.; García, T.; Mastral, A.M. Valorisation of waste tyre by pyrolysis in a moving bed reactor. Waste Manag. 2010, 30, 1220-1224. [CrossRef] [PubMed]

106. Jahirul, M.; Rasul, M.; Chowdhury, A.; Ashwath, N. Biofuels production through biomass pyrolysis-A technological review. Energies 2012, 5, 4952-5001. [CrossRef]

107. Roy, C.; Labrecque, B.; de Caumia, B. Recycling of scrap tires to oil and carbon black by vacuum pyrolysis. Resour. Conserv. Recycl. 1990, 4, 203-213. [CrossRef]

108. Roy, C.; Chaala, A.; Darmstadt, H. Vacuum pyrolysis of used tires end-uses for oil and carbon black products. J. Anal. Appl. Pyrolysis 1999, 51, 201-221. [CrossRef] 
109. Benallal, B.; Roy, C.; Pakdel, H.; Chabot, S.; Poirier, M.A. Characterization of pyrolytic light naphtha from vacuum pyrolysis of used tires-Comparison with petroleum naphtha. Fuel 1995, 74, 1589-1594. [CrossRef]

110. Mirmiran, S.; Pakdel, H.; Roy, C. Characterization of used tire vacuum pyrolysis oil: Nitrogenous compounds from the naphtha fraction. J. Anal. Appl. Pyrolysis 1992, 22, 205-215. [CrossRef]

111. Pakdel, H.; Pantea, D.M.; Roy, C. Production of dl-limonene by vacuum pyrolysis of used tires. J. Anal. Appl. Pyrolysis 2001, 57, 91-107. [CrossRef]

112. Lopez, G.; Olazar, M.; Aguado, R.; Elordi, G.; Amutio, M.; Artetxe, M.; Bilbao, J. Vacuum pyrolysis of waste tires by continuously feeding into a conical spouted bed reactor. Ind. Eng. Chem. Res. 2010, 49, 8990-8997. [CrossRef]

113. Roy, C.; Darmstadt, H.; Benallal, B.; Amen-Chen, C. Characterization of naphtha and carbon black obtained by vacuum pyrolysis of polyisoprene rubber. Fuel Process. Technol. 1997, 50, 87-103. [CrossRef]

114. Olazar, M.; San José, M.J.; Alvarez, S.; Morales, A.; Bilbao, J. Design of conical spouted beds for the handling of low-density solids. Ind. Eng. Chem. Res. 2004, 43, 655-661. [CrossRef]

115. Olazar, M.; Aguado, R.; Arabiourrutia, M.; Lopez, G.; Barona, A.; Bilbao, J. Catalyst effect on the composition of tire pyrolysis products. Energy Fuels 2008, 22, 2909-2916. [CrossRef]

116. López, G.; Olazar, M.; Aguado, R.; Bilbao, J. Continuous pyrolysis of waste tyres in a conical spouted bed reactor. Fuel 2010, 89, 1946-1952. [CrossRef]

117. Conesa, J.A.; Martín-Gullón, I.; Font, R.; Jauhiainen, J. Complete study of the pyrolysis and gasification of scrap tires in a pilot plant reactor. Environ. Sci. Technol. 2004, 38, 3189-3194. [CrossRef] [PubMed]

118. Zabaniotou, A.A.; Stavropoulos, G. Pyrolysis of used automobile tires and residual char utilization. J. Anal. Appl. Pyrolysis 2003, 70, 711-722. [CrossRef]

119. Huang, H.; Tang, L. Pyrolysis treatment of waste tire powder in a capacitively coupled RF plasma reactor. Energy Convers. Manag. 2009, 50, 611-617. [CrossRef]

120. Choi, G.-G.; Oh, S.-J.; Kim, J.-S. Non-catalytic pyrolysis of scrap tires using a newly developed two-stage pyrolyzer for the production of a pyrolysis oil with a low sulfur content. Appl. Energy 2016, 170, 140-147. [CrossRef]

121. Williams, P.T.; Bottrill, R.P.; Cunliffe, A.M. Combustion of tyre pyrolysis oil. Process Saf. Environ. 1998, 76, 291-301. [CrossRef]

122. Banar, M.; Akyildiz, V.; Özkan, A.; Çokaygil, Z.; Onay, Ö. Characterization of pyrolytic oil obtained from pyrolysis of TDF (tire derived fuel). Energy Convers. Manag. 2012, 62, 22-30. [CrossRef]

123. Díez, C.; Sánchez, M.E.; Haxaire, P.; Martínez, O.; Morán, A. Pyrolysis of tyres: A comparison of the results from a fixed-bed laboratory reactor and a pilot plant (rotatory reactor). J. Anal. Appl. Pyrolysis 2005, 74, 254-258. [CrossRef]

124. Gates, B.C.; Huber, G.W.; Marshall, C.L.; Ross, P.N.; Siirola, J.; Wang, Y. Catalysts for emerging energy applications. MRS Bull. 2008, 33, 429-435. [CrossRef]

125. Pandey, A.; Bhaskar, T.; Stöcker, M.; Sukumaran, R. Recent Advances in Thermochemical Conversion of Biomass; Elsevier: Amsterdam, The Netherlands, 2015.

126. Perego, C.; Bosetti, A. Biomass to fuels: The role of zeolite and mesoporous materials. Microporous Mesoporous Mater. 2011, 144, 28-39. [CrossRef]

127. Dũng, N.A.; Wongkasemjit, S.; Jitkarnka, S. Effects of pyrolysis temperature and Pt-loaded catalysts on polar-aromatic content in tire-derived oil. Appl. Catal. B Environ. 2009, 91, 300-307. [CrossRef]

128. Dũng, N.A.; Mhodmonthin, A.; Wongkasemjit, S.; Jitkarnka, S. Effects of ITQ-21 and ITQ-24 as zeolite additives on the oil products obtained from the catalytic pyrolysis of waste tire. J. Anal. Appl. Pyrolysis 2009, 85, 338-344. [CrossRef]

129. Dũng, N.A.; Tanglumlert, W.; Wongkasemjit, S.; Jitkarnka, S. Roles of ruthenium on catalytic pyrolysis of waste tire and the changes of its activity upon the rate of calcination. J. Anal. Appl. Pyrolysis 2010, 87, 256-262. [CrossRef]

130. Dũng, N.A.; Klaewkla, R.; Wongkasemjit, S.; Jitkarnka, S. Light olefins and light oil production from catalytic pyrolysis of waste tire. J. Anal. Appl. Pyrolysis 2009, 86, 281-286. [CrossRef]

131. Witpathomwong, C.; Longloilert, R.; Wongkasemjit, S.; Jitkarnka, S. Improving light olefins and light oil production using Ru/MCM-48 in catalytic pyrolysis of waste tire. Energy Procedia 2011, 9, 245-251. [CrossRef]

132. Shen, B.; Wu, C.; Liang, C.; Guo, B.; Wang, R. Pyrolysis of waste tyres: The influence of usy catalyst/tyre ratio on products. J. Anal. Appl. Pyrolysis 2007, 78, 243-249. 
133. Shen, B.; Wu, C.; Guo, B.; Wang, R.; Liang, C. Pyrolysis of waste tyres with zeolite USY and ZSM-5 catalysts. Appl. Catal. B Environ. 2007, 73, 150-157.

134. Williams, P.T.; Brindle, A.J. Aromatic chemicals from the catalytic pyrolysis of scrap tyres. J. Anal. Appl. Pyrolysis 2003, 67, 143-164. [CrossRef]

135. Williams, P.T.; Brindle, A.J. Catalytic pyrolysis of tyres: Influence of catalyst temperature. Fuel 2002, 81, 2425-2434. [CrossRef]

136. Williams, P.T.; Brindle, A.J. Fluidised bed catalytic pyrolysis of scrap tyres: Influence of catalyst: Tyre ratio and catalyst temperature. Waste Manag. Res. 2002, 20, 546-555. [CrossRef] [PubMed]

137. Muenpol, S.; Jitkarnka, S. Effects of Fe supported on zeolites on structures of hydrocarbon compounds and petrochemicals in waste tire-derived pyrolysis oils. J. Anal. Appl. Pyrolysis 2016, 117, 147-156. [CrossRef]

138. Li, W.; Li, H.; Li, D.; Li, X.; Huang, C.; Huo, P.; Wang, M.; Wang, M.; Wang, Y.; Han, L.; et al. Derived oil production by catalytic pyrolysis of scrap tires. Chin. J. Catal. 2016, 37, 526-532. [CrossRef]

139. Talip, Z.; Eral, M.; Hiçsönmez, Ü. Adsorption of thorium from aqueous solutions by perlite. J. Environ. Radioact. 2009, 100, 139-143. [CrossRef] [PubMed]

140. Shah, J.; Jan, M.R.; Mabood, F. Catalytic conversion of waste tyres into valuable hydrocarbons. J. Polym. Environ. 2007, 15, 207-211. [CrossRef]

141. Demirbas, A.; Al-Sasi, B.O.; Nizami, A.-S. Conversion of waste tires to liquid products via sodium carbonate catalytic pyrolysis. Energy Source Part A 2016, 38, 2487-2493. [CrossRef]

142. Qu, W.; Zhou, Q.; Wang, D.-Z.; Wang, Y.-Z.; Zhang, J.; Lan, W.-W.; Wu, Y.-H.; Yang, J.-W. Pyrolysis of waste tire on ZSM-5 zeolite with enhanced catalytic activities. Polym. Degrad. Stab. 2006, 91, 2389-2395. [CrossRef]

143. Ahoor, A.H.; Zandi-Atashbar, N. Fuel production based on catalytic pyrolysis of waste tires as an optimized model. Energy Convers. Manag. 2014, 87, 653-669. [CrossRef]

144. Wey, M.-Y.; Liou, B.-H.; Wu, S.-Y.; Zhang, C.-H. The autothermal pyrolysis of waste tires. J. Air Waste Manag. Assoc. 1995, 45, 855-863. [CrossRef]

145. Debek, C.; Walendziewski, J. Hydrorefining of oil from pyrolysis of whole tyres for passenger cars and vans. Fuel 2015, 159, 659-665. [CrossRef]

146. Onay, O. Influence of pyrolysis temperature and heating rate on the production of bio-oil and char from safflower seed by pyrolysis, using a well-swept fixed-bed reactor. Fuel Process. Technol. 2007, 88, 523-531. [CrossRef]

147. Murugan, S.; Ramaswamy, M.C.; Nagarajan, G. The use of tyre pyrolysis oil in diesel engines. Waste Manag. 2008, 28, 2743-2749. [CrossRef] [PubMed]

148. Arpa, O.; Yumrutas, R. Experimental investigation of gasoline-like fuel obtained from waste lubrication oil on engine performance and exhaust emission. Fuel Process. Technol. 2010, 91, 197-204. [CrossRef] 